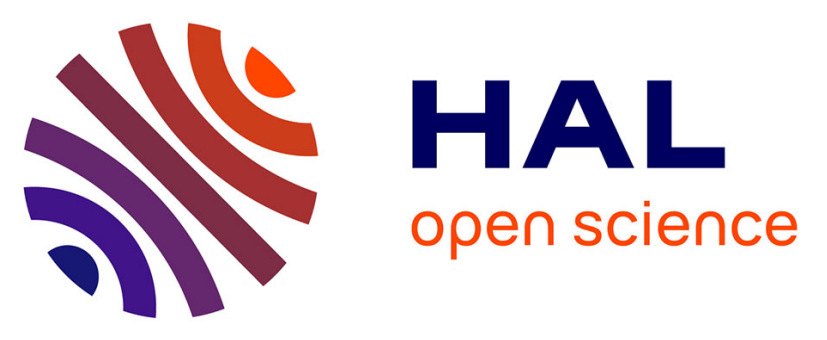

\title{
Platinum complexes inhibit HER-2 enriched and triple-negative breast cancer cells metabolism to suppress growth, stemness and migration by targeting PKM/LDHA and CCND1/BCL2/ATG3 signaling pathways
}

Xue Bai, Amjad Ali, Zhimin Lv, Na Wang, Xing Zhao, Huifang Hao, Yongmin Zhang, Faizur Rahman

\section{- To cite this version:}

Xue Bai, Amjad Ali, Zhimin Lv, Na Wang, Xing Zhao, et al.. Platinum complexes inhibit HER-2 enriched and triple-negative breast cancer cells metabolism to suppress growth, stemness and migration by targeting PKM/LDHA and CCND1/BCL2/ATG3 signaling pathways. European Journal of Medicinal Chemistry, 2021, 224, pp.113689. 10.1016/j.ejmech.2021.113689 . hal-03297125

\section{HAL Id: hal-03297125 \\ https: / hal.sorbonne-universite.fr/hal-03297125}

Submitted on 23 Jul 2021

HAL is a multi-disciplinary open access archive for the deposit and dissemination of scientific research documents, whether they are published or not. The documents may come from teaching and research institutions in France or abroad, or from public or private research centers.
L'archive ouverte pluridisciplinaire HAL, est destinée au dépôt et à la diffusion de documents scientifiques de niveau recherche, publiés ou non, émanant des établissements d'enseignement et de recherche français ou étrangers, des laboratoires publics ou privés. 


\title{
Platinum complexes inhibit HER-2 enriched and triple-negative breast cancer cells metabolism to suppress growth, stemness and migration by targeting PKM/LDHA and CCND1/BCL2/ATG3 signaling pathways
}

Xue Bai ${ }^{\mathrm{a}, 1}$, Amjad Ali ${ }^{\mathrm{b}, \mathrm{c}, 1}$, Zhimin Lvª ${ }^{\mathrm{a}}$, Na Wang ${ }^{\mathrm{a}}$, Xing Zhao ${ }^{\mathrm{a}}$, Huifang Hao ${ }^{\mathrm{a}, \mathrm{d}}$, Yongmin Zhang ${ }^{\mathrm{a}, \mathrm{e}, *}$ and Faiz-Ur Rahman ${ }^{\mathrm{a}, *}$

anner Mongolia University Research Center for Glycochemistry of Characteristic Medicinal Resources, School of Chemistry and Chemical Engineering, Inner Mongolia University, Hohhot 010021, People’s Republic of China.

bInstitute of Integrative Biosciences, CECOS University of IT and Emerging Sciences, Peshawar, KPK, Pakistan.

'Institute of Biomedical Sciences, School of Life Sciences, East China Normal University, 500 Dongchuan Road, Shanghai, 200241, People's Republic of China.

dSchool of Life Sciences, Inner Mongolia University, Hohhot 010021, People's Republic of China

'Sorbonne Université, CNRS, Institut Parisien de Chimie Moléculaire, UMR 8232, 4 Place Jussieu, 75005 Paris, France.

*Corresponding Authors. E-mail: yongmin.zhang@upmc.fr (Y. Zhang), faiz@imu.edu.cn (F.-U. Rahman)

\begin{abstract}
Triple-negative-breast cancer (TNBC) and HER-2 enriched positive aggressive types of breast cancer and are highly metastatic in nature. Anticancer agents those target TNBC and HER-2 enriched positive breast cancers are considered important in the field of breast cancer research. In search of the effective anticancer agents, we synthesized Pt(II) complexes to target these cancers. Platinum complexes (C1-C8) were prepared in single step by the reaction of commercially available $\mathrm{K} 2 \mathrm{PtCl} 4$ with the readily prepared ligands (L1-L8). All these compounds were characterized successfully by different spectroscopic and spectrophotometric analyses. Structures of C1, C3 and C8 were characterized by single crystal X-ray analysis that confirmed the exact chelation mode of the SNO-triply coordination ligand. All these complexes inhibited the in vitro growth of MCF-7 (luminal-like), MDA-MB-231(TNBC) and SKBR3 (HER-2 enriched) breast cancer cells. C1, C3 and C7 induced cell death and suppressed the clonogenic potential of these cancer cells. Importantly, C1, C3 and $\mathbf{C 7}$ showed potentials to suppress cancer stem cells/mammosphere formation and cell migration ability of MDA-MB-231 and SKBR3 breast cancer
\end{abstract}

\footnotetext{
${ }^{1}$ These authors have equal contribution
} 
cells. These complexes also induced cellular senescence in MDA-MB-231 and SKBR3, thus suggesting a cell retardation mechanism. Similarly, these complexes induced DNA damage by activating p-H2AX expression and promoted autophagy via ATG3/LC3B axis activation in MDA-MB-231 and SKBR3 cells. Furthermore, these complexes decreased the expression of oncogenic proteins such as BCL2 and cylin-D1 those are involved in cancer cell survival and cell cycle progression. To further gain insight, we found that $\mathbf{C 1}$ and $\mathbf{C} 7$ targeted glycolytic pathways by regulating PKM and LDHA expression, which are involved in glycolysis. Moreover, $\mathbf{C 1}$ and $\mathbf{C} 7$ suppressed the formation of ATP production that is required for cancer cell growth. Taken together, the easy synthesis and biological assays results point towards the importance of these complexes in MDA-MB-231(TNBC) and SKBR3 (HER-2 enriched) breast cancer cells by targeting multiple signaling pathways those are considered important during breast cancer progression. This study produces bases for further deeper in vitro or in vivo study that could lead to the effective breast cancer agents which we are working on.

\section{Keywords}

Platinum complexes, anticancer study, breast cancer, cancer cell migration, cells stemness.

\section{Introduction}

Platinum-based chemotherapeutic agents prescription to cancer patients with multiple malignancies made them the desired drugs in clinical chemotherapy regimens [1], over 50\% of cancer treatments were based on platinum-based drugs. [2-4] The discovery and seminal work in platinum anticancer area was reported by Rosenberg and coworkers in late 70s. [5-9] Since then platinum coordination complexes are used as active inorganic antitumor drugs. [10] After the approval and successes of cisplatin as an anticancer drug, later on five other new platinum complexes were approved as anticancer drugs locally or globally tabulated in Fig. 1 with time of their approval. [11] 

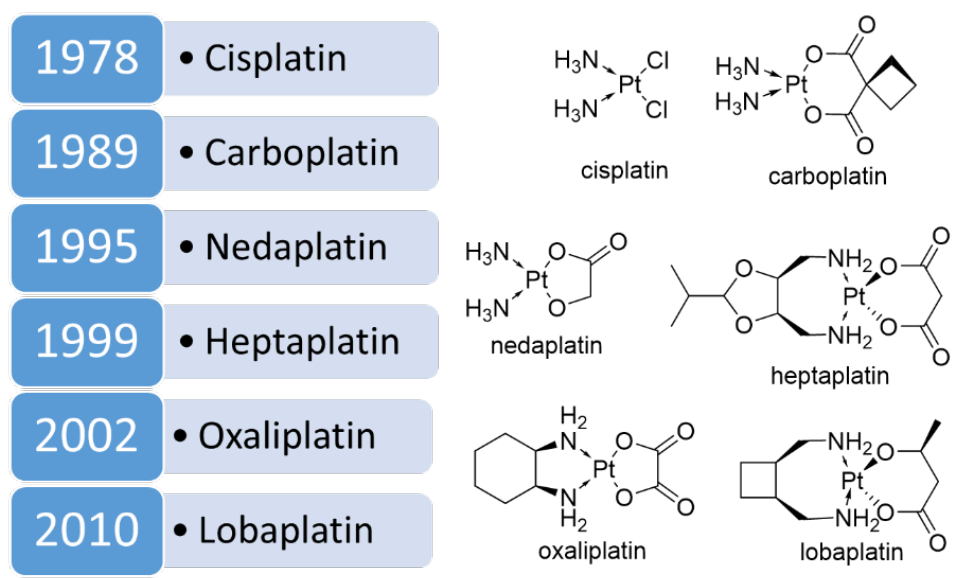

Fig. 1 Clinically administered (Approved) anticancer drugs of platinum metal, the year it is approved

Several draw backs associated with platinum-based drugs were reported including resistance and other physiological issues in cancer patients. [12-15] Therefore, a large number of recent studies were conducted to overcome resistance, improve the safety or decrease side effects and efficacy of platinum chemotherapeutic drugs. A number of approaches including ligand modifications, incorporation of biomolecules derived assemblies, conjugation with other clinically approved drugs, delivery vehicles etc. were used to decrease these side effects in cancer patients. [11, 16-22] Similarly, these newly assembled platinum-based anticancer agents using different coordinating assemblies changed their targets inside cancer cells. [21, 23-29] Several new platinum-based complexes were synthesized and investigated for their anticancer properties, some of them were used or rejected in clinical trials and a number of them are currently in clinical trials or finding their ways to be approved as anticancer drugs. [3, 14, 25, 30-34] The development of novel platinum-based effective anticancer agents is still an important area in provision of bases for the future development of anticancer drugs. These new and effective platinum-based chemotherapeutic agents used in preclinical and clinical trials for the future discovery of cancer treatments will further affect the survival and relapse of cancer patients. [35]

Breast cancer is among the most aggressive types of human cancers and survival rate of breast cancer patients is also poor as compared to other types of human cancers. Cancer metastasis is one of the leading causes of breast cancer related to mortality and morbidity. [36] Breast cancer has different molecular subtypes including Luminal-A, triple-negative and HER-2 enriched. Luminal-like breast cancers are less aggressive and less metastatic in nature. Triple negative breast cancer is aggressive type of breast cancer and highly associated with metastatic potential. [37, 38] HER-2 enriched breast cancer subtypes are also aggressive in nature and amplification of HER-2 gene is involved in breast cancer cell growth, survival, invasion and metastasis. [39] Breast cancer has ability to metastasize to other parts of the body such as to 
lungs, brain, liver and bone. Triple-negative-breast cancer (TNBC) is very aggressive in nature. Mutantp53 is one of the key players that plays a key role in the progression of triple-negative breast cancer. TNBC involved amplification of several key oncogenic signaling pathways, gain of function of oncogenes and loss of several important tumor suppressor proteins. TNBC patient's survival rate is very poor due to its aggressive nature and high metastatic potential. [40,41] Currently there are very limited treatment options for TNBC and chemotherapy is considered important treatment option for TNBC patients. Moreover, HER-2 positive breast cancer involved over-expression of HER-2 oncogene. HER-2 oncogene plays important role in regulation of several oncogenic signaling pathways such as mitogen activated kinases that are involved in cancer cell survival, invasion and metastasis. HER-2 breast cancer also has limited therapeutic options due to amplification of HER-2 that promote the growth of oncogenic proteins. [42] Due to the limited therapeutic options for both TNBC and HER-2 positive breast cancer design and synthesis of novel anticancer agents those effective against TNBC and HER-2 positive breast cancer cells are considered important in the field of medical chemistry and required on urgent basis for effective clinical and pre-clinical trials.

In the present study we reported the synthesis of platinum(II) complexes from readily available precursors in excellent isolated yields. These complexes were thoroughly characterized for their structure and stabilities using NMR and spectrophotometric methods. The mandatory structure and coordination of ligand to Pt center was also confirmed in solid state using single crystal X-ray analysis. We checked their anticancer activities against different molecular subtypes of breast cancer including Luminal-like, TNBC and HER-2 positive cells. These complexes suppressed the growth and clonogenic potentials of breast cancer cells. Highly active three selected complexes among these were analyzed for cancer stem cells formation, cell migration and cellular senescence in both MDA-MB-231 and SKBR3 cells. These complexes regulated DNA damage as evident by $\mathrm{p}-\mathrm{H} 2 \mathrm{AX}$ expression and induced autophagy by targeting ATG3/LC3B expressions. Moreover, inhibition of oncogenic proteins BCL2 and cyclinD1 expressions was observed in both TNBC and HER-2 enriched breast cancer cells. They targeted cancer cell metabolism by regulating glycolytic genes such as PKM and LDHA expression in breast cancer cells.

\section{Results}

\subsection{Chemistry}

\subsubsection{Synthesis and characterization of the ligands (L1-L8) and platinum complexes (C1-C8)}


Tridentate ligands (L1-L8) were prepared by mixing 2(phenylthio)aniline and substituted salicylaldehyde in ethanol under reflux conditions, after completion of the reaction (checked by TLC) the mixture was cooled in refrigerator to precipitate each ligand. Pt(II) complexes (C1-C8) were prepared by reaction of 1 equivalent of $\mathrm{K}_{2} \mathrm{PtCl}_{4}$ with an equivalent amount of each ligand in the presence of 1 equivalent of $\mathrm{NaOAc}$ as a base. All these ligands and complexes were obtained in excellent isolated yields (Scheme 1). Similarly, structure of each ligand or complex was characterized by NMR spectroscopy and HR-ESI mass spectrometry (ESI Fig. S1-S46). C1, C3, C8 structures were determined in solid state using single crystal X-rays.

${ }^{1} \mathrm{H}$ NMR spectra of each ligand (L1-L8) showed a singlet for phenolic proton observed in the most downfield region from 12.59-15.23 ppm (ESI Fig. S1-S15). The second most downfield chemical shifts was observed for imine proton of each ligand observed in the region between 8.56-9.39 ppm. Similarly, other protons attached to aromatic rings were found in the aromatic region 8.40-6.84 ppm. The reaction of each ligand with Pt salt to produce C1-C8, different changes were observed in the ${ }^{1} \mathrm{H}$ NMR chemical shifts. The expected disappearance of $\mathrm{OH}$ proton of each ligand showed that Pt covalent bond was formed with $\mathrm{O}$ atom of the ligand in each complex. The most downfield chemical shift for C1-C8 was the imine proton that was observed in the range 9.66-10.11 ppm for each complex (ESI Fig. S15-31). The overall results showed the imine proton of each ligand was shifted downfield after coordination with Pt. Similarly, the imine proton chemical shift was broad at the base showing proton coupling with Pt but the coupling constant $\left(J_{\mathrm{Pt}-\mathrm{H}}\right)$ was smaller to calculate $J$ value as we observed in our previous work. [43] All the aromatic protons chemical shifts were also shifted downfield in C1-C8 as compared to the precursor ligand. Similarly, prominent overall changes were observed in ${ }^{13} \mathrm{C}$ NMR chemical shifts of each complex as compared to the precursor ligand (ESI Fig. S15-31). Ligand (L1-L8) was symmetrical while after coordination with $\mathrm{Pt}$, the complex formed was a racemic mixture bearing $\mathrm{S}$ atom as stereo-center. Both these stereo-isomers were discussed in single crystal section while it was difficult to separate these isomers. 


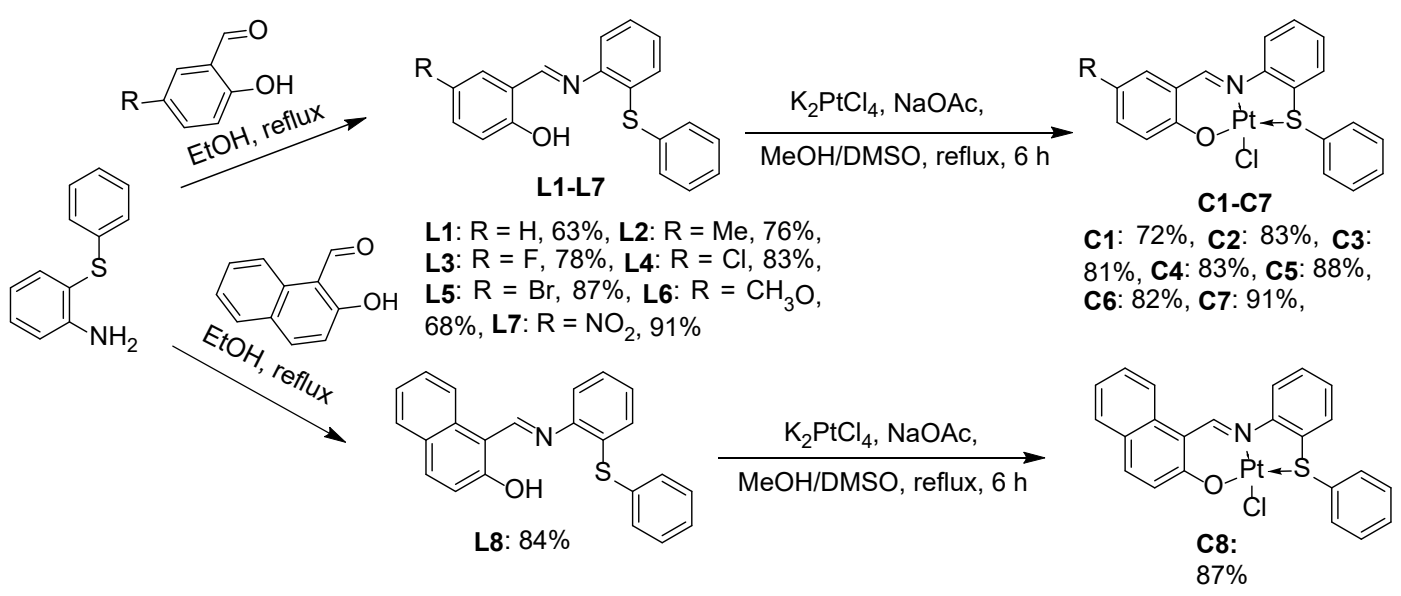

Scheme 1. Synthetic scheme for ligands (L1-L4) and Pt(II) complexes (C1-C8)

\subsubsection{Single crystal description of $\mathbf{C 1}, \mathbf{C} 3$, and $\mathbf{C} \mathbf{8}$}

C1, $\mathbf{C 3}$ and $\mathbf{C 8}$ were crystalized from $\mathrm{CH}_{2} \mathrm{Cl}_{2}-$ n-hexane solution by slow evaporation to get single crystal suitable for X-ray analyses. The ORTEP diagram of the crystal of each complex was plotted in Fig. 2 and structure refinement parameters were displayed in Table 1. $\mathbf{C 1}$ and $\mathbf{C 3}$ crystalized in orthorhombic while C8 in monoclinic crystal systems. The coordination sphere of $\mathrm{Pt}$ was consisted of $\mathrm{S}, \mathrm{N}, \mathrm{O}$ and $\mathrm{Cl}$ donor atoms in which $\mathrm{SNO}$ atoms were parts of the ligand while the fourth one was $\mathrm{Cl}$ ancillary or labile ligand. In all these complexes Pt adopted square planner symmetry. The coordination of the ligand to Pt formed a stereo center at $\mathrm{S}$ donor atom, both $R$ and $S$ isomers were observed in the single crystal displayed by a curved arrow in the ORTEP plot for each complex (Fig. 2). In crystal packing of $\mathbf{C 1}$ and $\mathbf{C 3}$ short interaction was observed between $\mathrm{Pt}(1)$ and $\mathrm{C}(10)$ that helped in formation of 1D chains in crystal packing, those interacted with other chains through multiple hydrogen bonding to facilitate the 3D arrangement of molecules in crystal packing (ESI Fig. S47-S48). In crystal packing of C8 $\pi$ - $\pi$ stacking was observed between the naphthalene part of one complex with thioanline ring of the other molecule. These stacking arranged molecules in 1D chains, further hydrogen bonding between these 1D chains arranged molecules in 3D packing (ESI Fig. S49).

Table 1 Structure refinement parameters of C1, C3, and C8

\begin{tabular}{llll}
\hline & $\mathbf{C 1}$ & $\mathbf{C 3}$ & $\mathbf{C 8}$ \\
\hline Empirical formula & $\mathrm{C}_{19} \mathrm{H}_{14} \mathrm{ClNOPtS}$ & $\mathrm{C}_{19} \mathrm{H}_{13} \mathrm{ClFNOPtS}$ & $\mathrm{C}_{23} \mathrm{H}_{16} \mathrm{ClNOPtS}$ \\
Formula weight & 534.91 & 552.90 & 584.97 \\
Temperature $(\mathrm{K})$ & $150.00(10)$ & $150.00(10)$ & $150.00(10)$ \\
Crystal system & Orthorhombic & Orthorhombic & Monoclinic \\
Space group & Pbca & Pbca & $\mathrm{P} 2{ }_{1} / \mathrm{c}$
\end{tabular}




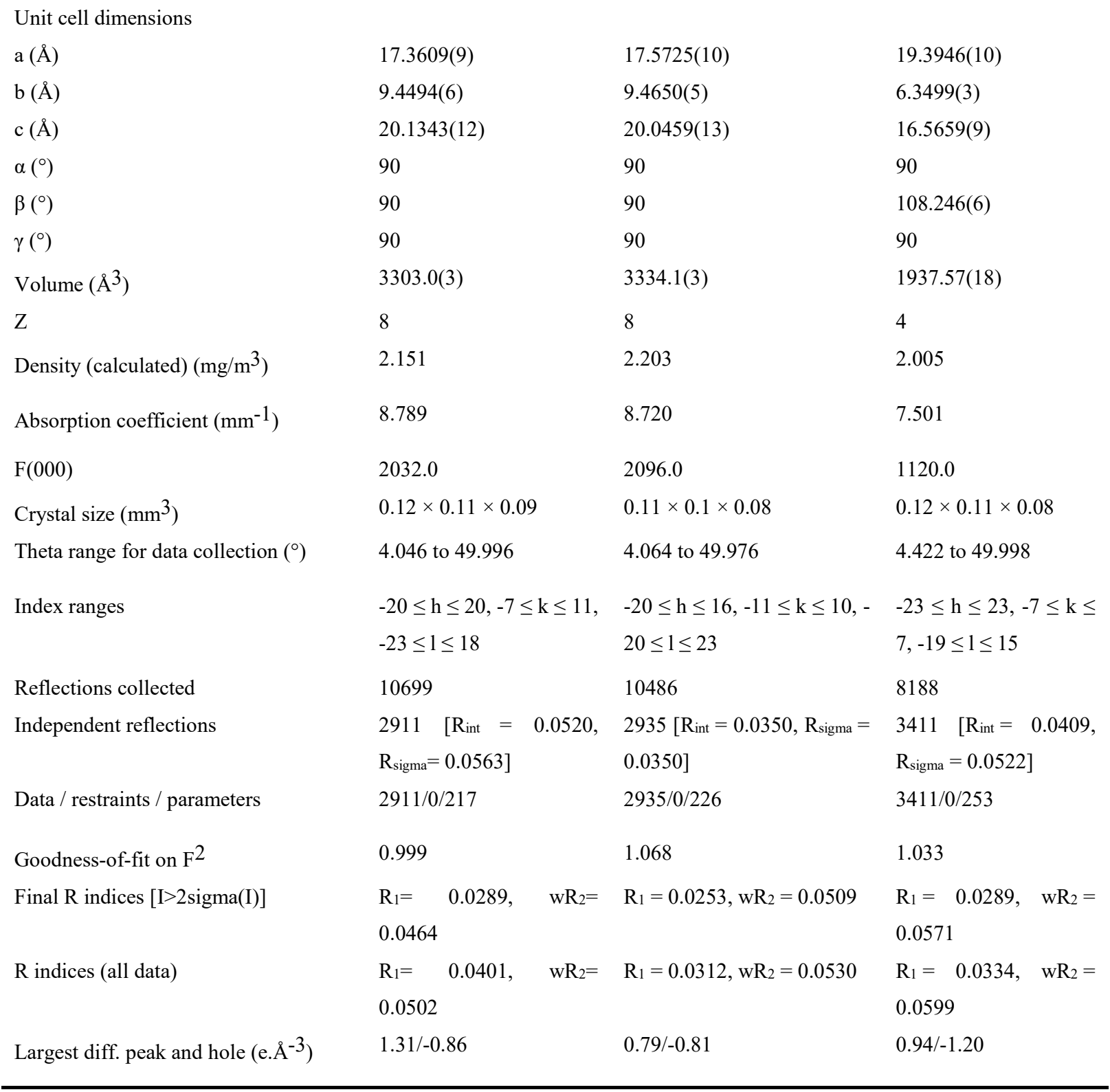

${ }^{[\mathrm{a}]} \mathrm{R}_{1}=\Sigma_{\text {all reflections }}\left|\mathrm{F}_{0}-\mathrm{F}_{\mathrm{c}}\right| \Sigma_{\text {all reflections }}\left|\mathrm{F}_{0}\right|,{ }^{[\mathrm{b}]} \mathrm{wR}_{2}=\left[\Sigma \mathrm{w}\left(\mathrm{F}_{0}^{2}-\mathrm{F}_{\mathrm{c}}{ }^{2}\right)^{2} / \Sigma\left(\mathrm{w}\left(\mathrm{F}_{0}^{2}\right)^{2}\right)\right]^{1 / 2}$.

Bond lengths and angles around Pt center for each $\mathbf{C 1}, \mathbf{C 3}$, and $\mathbf{C 8}$ were given in Table 2. The bond lengths of each atom of the ligand coordinated with Pt center in $\mathbf{C 1}$ and $\mathbf{C 3}$ were almost similar while different from those of C8. (Table 2 entry 1-4). The longest bond length in each complex was between $\mathrm{Pt}(1)$ and $\mathrm{Cl}(1)$ while the shortest one was $\mathrm{Pt}(1)-\mathrm{N}(1)$. This trend was common all these three complexes (Table 1 entry 4). The sum of all bond angles around Pt center in all these three complexes was $360^{\circ}$. Similar trend was found in bond angles in all these three complexes, the bond angles of $\mathbf{C 1}$ and $\mathbf{C 3}$ were almost similar but different as compared to C8. The angle among $\mathrm{N}(1), \operatorname{Pt}(1)$ and $\mathrm{O}(1)$ was found the biggest in all these complexes while the smallest angle in each complex was different compared to the 
other. The ligand around Pt center in all these three complexes occupied almost planner symmetry and inter plane stacking was observed in crystal packing of each complex.
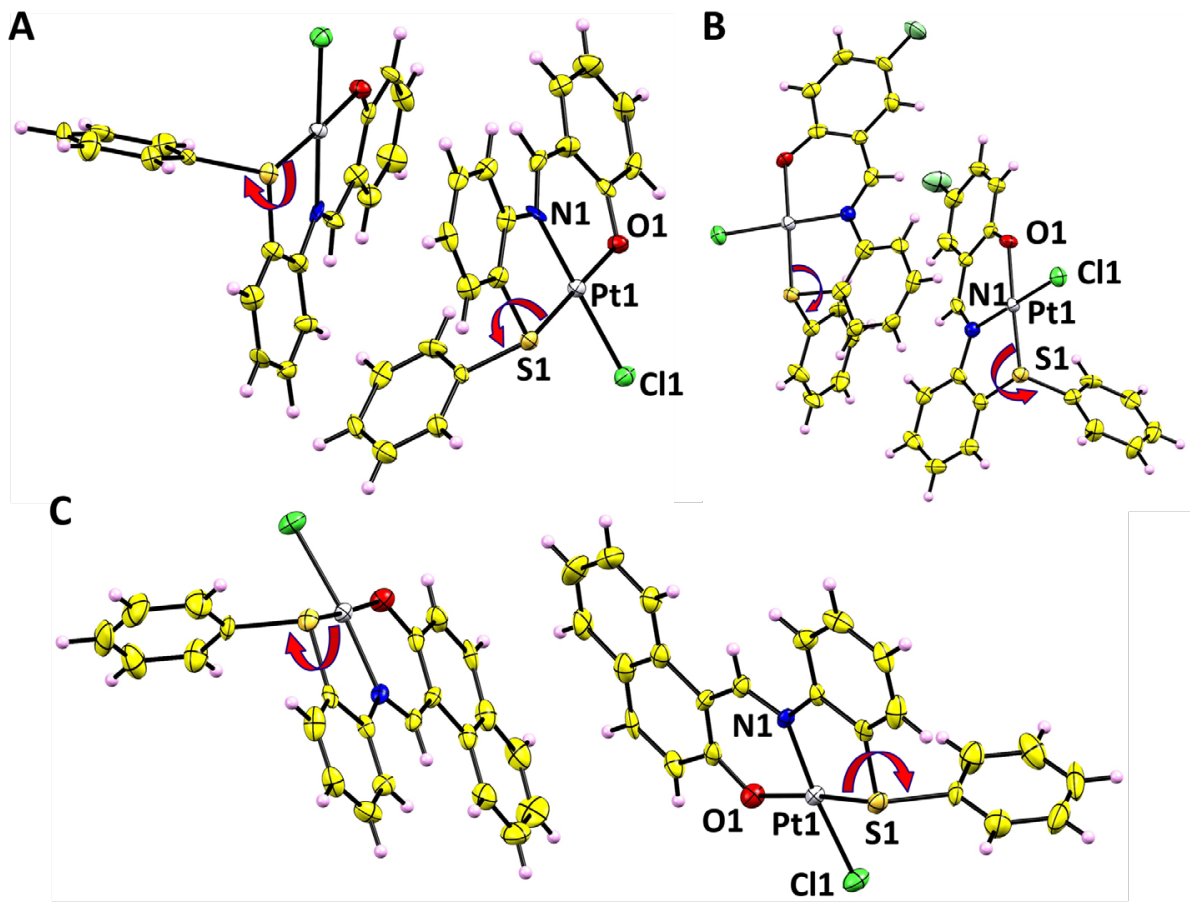

Fig. 2. ORTEP plot of $\mathbf{C 1}$ (A), C3 (B) and $\mathbf{C 8}(\mathrm{C})$ at 70\% ellipsoids probability; The arrow showed $R$ and $S$ stereo isomers as each complex was a racemic mixture at $\mathrm{S}$ as stereo center.

Table 2. Selected bond lengths $(\AA)$ and angles $\left(^{\circ}\right)$ around Pt atom in each complex

\begin{tabular}{lllll}
\hline Entry & Bond/Angle & $\mathbf{C 1}$ & $\mathbf{C 3}$ & $\mathbf{C 8}$ \\
\hline Bond length $(\AA)$ & & & \\
1 & $\mathrm{Pt}(1)-\mathrm{Cl}(1)$ & $2.3122(12)$ & $2.3092(12)$ & $2.3084(12)$ \\
2 & $\mathrm{Pt}(1)-\mathrm{S}(1)$ & $2.2286(14)$ & $2.2291(12)$ & $2.2180(13)$ \\
3 & $\mathrm{Pt}(1)-\mathrm{O}(1)$ & $1.995(4)$ & $1.998(3)$ & $1.991(3)$ \\
4 & $\mathrm{Pt}(1)-\mathrm{N}(1)$ & $1.990(4)$ & $1.990(4)$ & $1.986(4)$ \\
Bond angle $\left({ }^{\circ}\right)$ & & & \\
5 & $\angle \mathrm{S}(1)-\mathrm{Pt}(1)-\mathrm{Cl}(1)$ & $91.18(5)$ & $90.97(4)$ & $92.50(5)$ \\
6 & $\angle \mathrm{O}(1)-\mathrm{Pt}(1)-\mathrm{Cl}(1)$ & $87.45(9)$ & $87.45(9)$ & $87.05(10)$ \\
7 & $\angle \mathrm{O}(1)-\operatorname{Pt}(1)-\mathrm{S}(1)$ & $177.86(10)$ & $178.01(9)$ & $173.40(10)$ \\
8 & $\angle \mathrm{N}(1)-\operatorname{Pt}(1)-\mathrm{Cl}(1)$ & $177.69(12)$ & $177.71(11)$ & $174.48(11)$ \\
9 & $\angle \mathrm{N}(1)-\mathrm{Pt}(1)-\mathrm{S}(1)$ & $87.34(13)$ & $87.74(11)$ & $87.23(11)$ \\
10 & $\angle \mathrm{N}(1)-\operatorname{Pt}(1)-\mathrm{O}(1)$ & $94.07(15)$ & $93.88(14)$ & $93.85(14)$ \\
\hline
\end{tabular}




\subsubsection{Stability and hydrolysis of reference complexes $\boldsymbol{C 1}, \boldsymbol{C} 3$ and $\mathbf{C} \boldsymbol{8}$}

For biological analyses platinum complexes or drugs are dissolved in organic solvents mostly in DMSO or their mixture with water due to the low or no solubility in water. In cells it is believed that platinum complexes are aquated by water and the ancillary or labile ligand is exchanged with water. This aquation is a mandatory first step in cancer cells that produces the active complex which coordinates with other biomolecules and finally reach to the nucleus to attach the final target DNA. The coordination of platinum complex to DNA suppresses DNA replication and thereby kill cancer cell. Therefore the degree of aquation of a particular platinum complex affects its biological or anticancer effect. [44-47]. In the presence of DMSO as co-solvent the ancillary ligand is replaced by DMSO and this ligand exchange changes the coordination environment of $\mathrm{Pt}$ and thereby affects its chemotherapeutic properties.

We analyzed C1, C3 and C8 for their in vitro stability using ${ }^{1} \mathrm{H}$ NMR methods (Fig. 3A, C, E and ESI Fig. S50-S52). Firstly we used pure DMSO- $d_{6}$ and we did not find any change in the protons chemical shifts showing these complexes were highly stable in DMSO- $d_{6}$ and did not pursue ancillary ligand exchange (ESI Fig. S53). Secondly we checked their stability in $15 \% \mathrm{D}_{2} \mathrm{O} / \mathrm{DMSO}-d_{6}$ mixture by repeated ${ }^{1} \mathrm{H}$ NMR spectroscopic analyses. We observed aquation and further ancillary ligand exchange with DMSO- $d_{6}$ over time as the ancillary ligand aquation occurred by water and that was further replace by DMSO as shown in scheme 2. This equilibrium was achieved in $5 \mathrm{~h}$ and remained unchanged over 7 days (Fig. 3A, C, E).

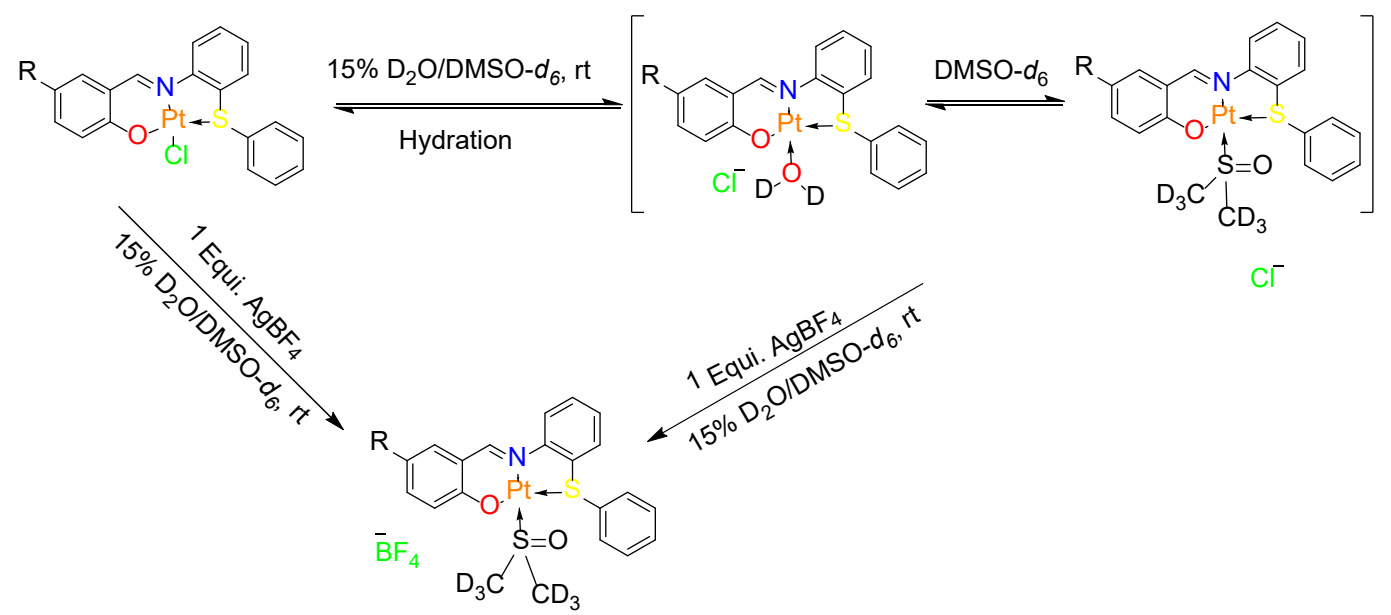

Scheme 2 Ancillary ligand aquation in each complex by water and further exchange by DMSO- $d_{6}, \mathrm{AgBF}_{4}$ abstracted the ancillary chloride for form mixed ligand complexes with $\mathrm{BF}_{4}$ anions.

The aquation and further replacement of the ancillary chloride ligand by DMSO- $d_{6}$, the ${ }^{1} \mathrm{H}$ NMR signals were prominently changed in positions and the same number of protons chemical shifts were observed. Each signal was shifted up field or downfield depending on its proximity to Pt center. HR ESI-MS 
analysis was performed for each of the final sample to see $\mathrm{m} / z$ signal for DMSO- $d_{6}$ exchanged complex. In each mass spectrum single positively charged specie with $m / z$ equal to $\left[\mathrm{M}-\mathrm{BF}_{4}\right]^{+}$was observed (Fig. 3B, D, F and ESI Fig. S50-S52). These analyses confirmed ancillary ligand aquation and replacement by DMSO- $d_{6}$ of these reference complexes.

\section{A}

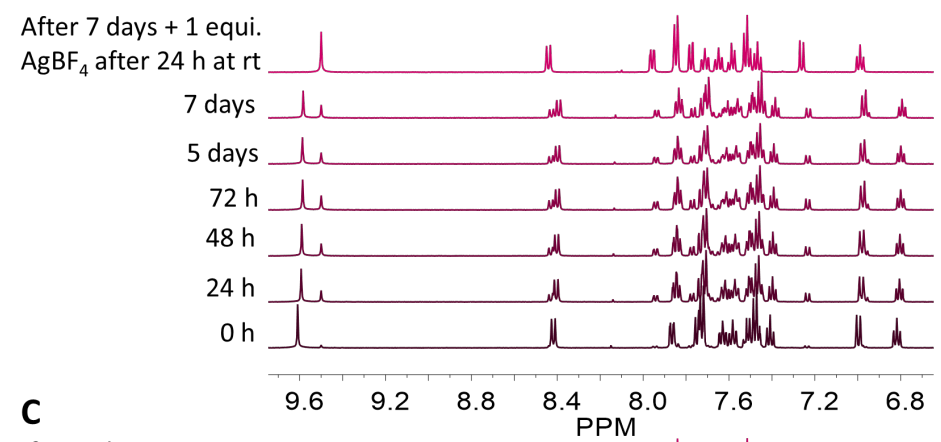

After 7 days +1 equi. $\mathrm{AgBF}_{4}$ after $24 \mathrm{~h}$ at rt

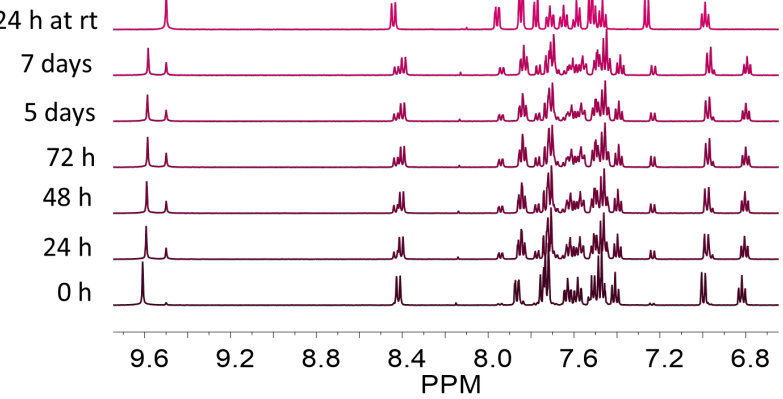

E

After 7 days +1 equi. $\mathrm{AgBF}_{4}$ after $24 \mathrm{~h}$ at rt

7 days

5 days

$72 \mathrm{~h}$

$48 \mathrm{~h}$

$24 \mathrm{~h}$

$\mathrm{Oh}$

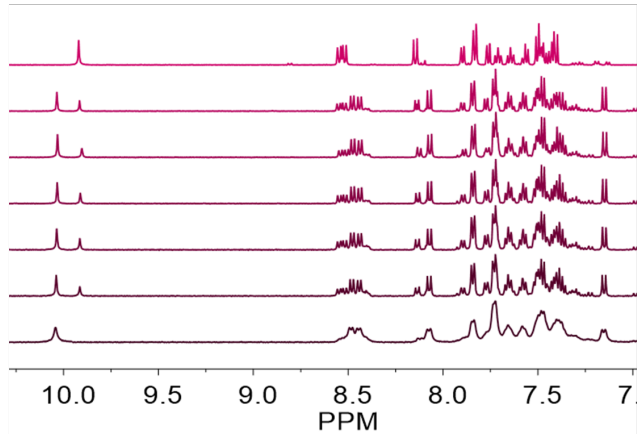

B
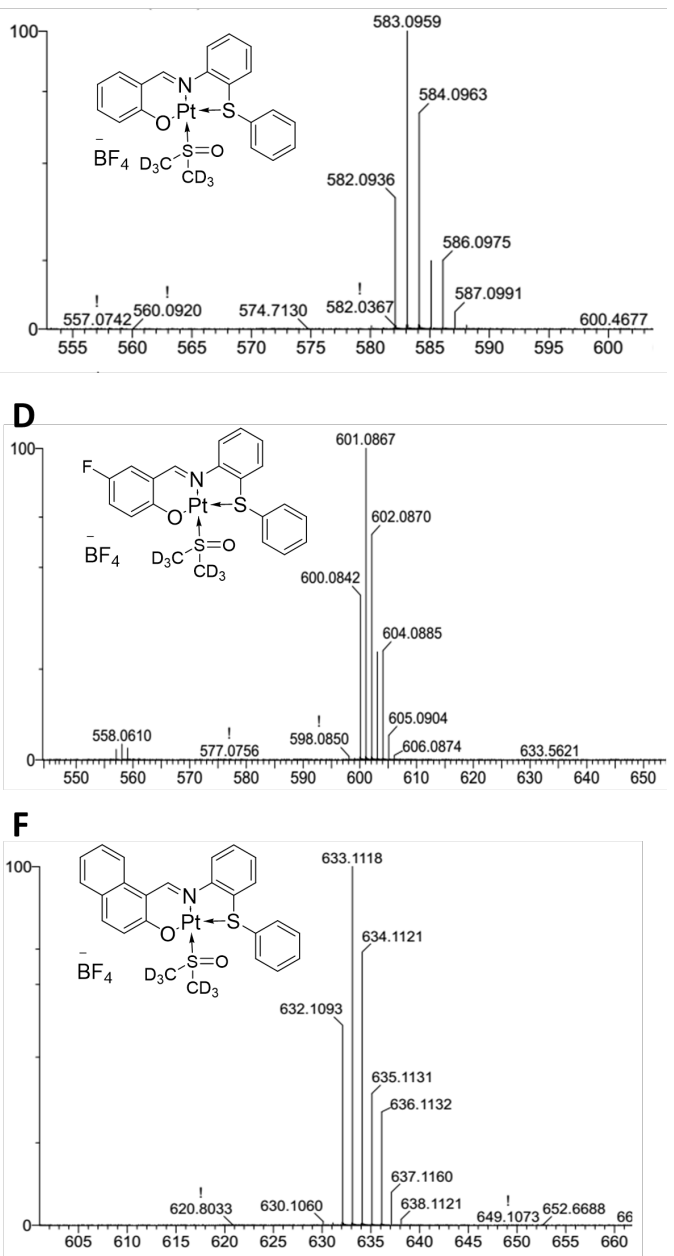

Fig. 3 Stability analyses of C1, C3 and C8; A, C, E ${ }^{1} \mathrm{H}$ NMR spectra plot over mentioned time point in $15 \% \mathrm{D}_{2} \mathrm{O} / \mathrm{DMSO}-d_{6}, \mathrm{C}$, D, F HR ESI-MS spectra of the displayed complexes formed after the ancillary chloride ligand exchange.

\subsection{Biology}

\subsubsection{Pt(II) complexes suppressed cancer cell growth}

Breast cancer metastases is one of the leading cause of cancer associated mortality worldwide. Metastatic breast cancer is very aggressive in nature and chemotherapeutic resistance is common to effectively kill these cells. Therefore, we choose different molecular subtypes of breast cancer cells including MCF-7 
(luminal-like breast cancer cells), MDA-MB-231 (triple negative breast cancer cells) and SKBR3 (HER-2 enriched breast cancer cells). We treated MCF-7, MDA-MB-231 and SKBR3 cells with $20 \mu \mathrm{M}$ of C1-C8 for $48 \mathrm{~h}$ and then cell viability was determined. We observed strong cytotoxic effect of C1-C7 while C8 showed mild effect in MCF-7 cells (Fig. 4A-C). Similarly, in SKBR3 cells C1, C3, C6 and C7 showed strong cytotoxic effect as compared to C2, C4, C5 and C8. Moreover, MTT assay showed significant cytotoxic effect of C1-C8 on the growth and survival of MDA-MB-231 cancer cells, which are highly metastatic and aggressive in nature. These results suggested C1-C8 have potential to retard different breast cancer cell growth.

As our results indicated that $\mathbf{C} 1$ has consistently strong cytotoxic effect on all MCF-7, MDA-MB-231 and SKBR3 cells, therefore we tested different concentrations of $\mathbf{C 1}$ on these breast cancer cell lines (Fig. 4DF). MTT assay suggested that $2.5 \mu \mathrm{M}$ of $\mathbf{C 1}$ has good effect on cell growth inhibition of MCF-7 cells in comparison to $0.5 \mu \mathrm{M}$ and $1 \mu \mathrm{M}$. Moreover, we observed that $5 \mu \mathrm{M} \mathrm{C1}$ was sufficient to suppress both MDA-MB-231 and SKBR3 cell growth. Taken together, these results suggested that $\mathbf{C 1}$ could be an important complex among its family members due to its strong inhibitory effect on different molecular subtypes of breast cancer.

A

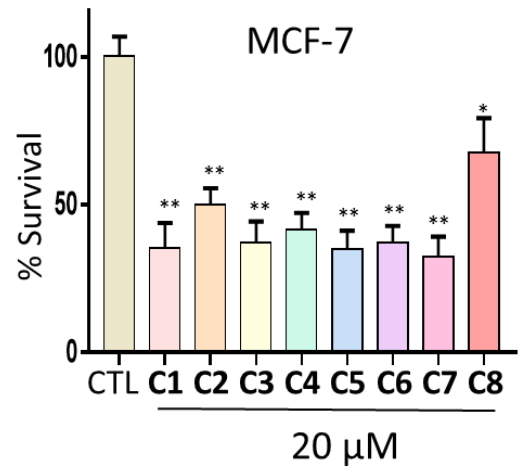

D

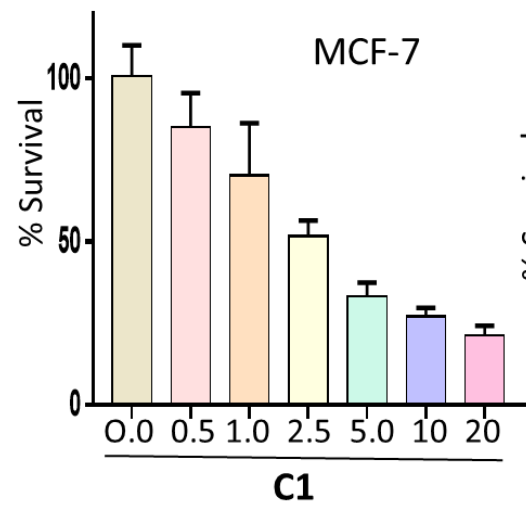

B

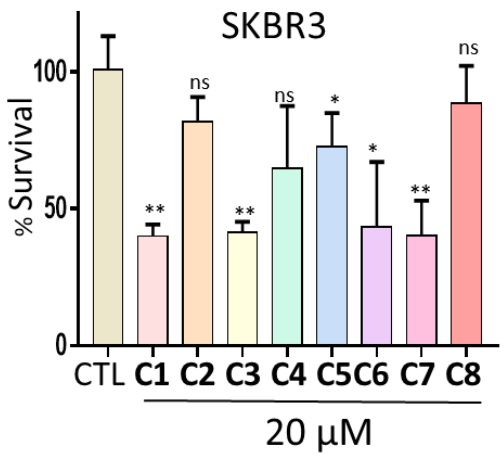

E

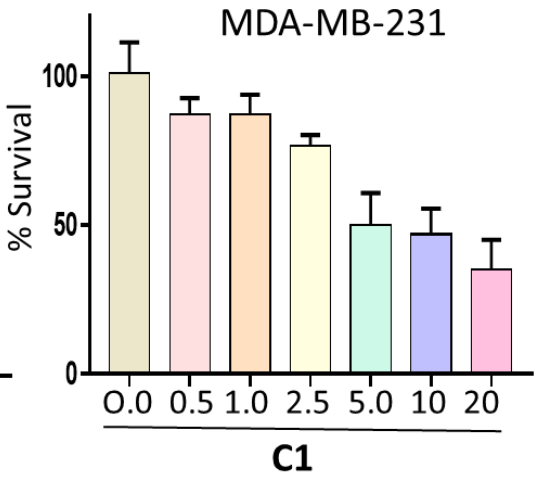

C

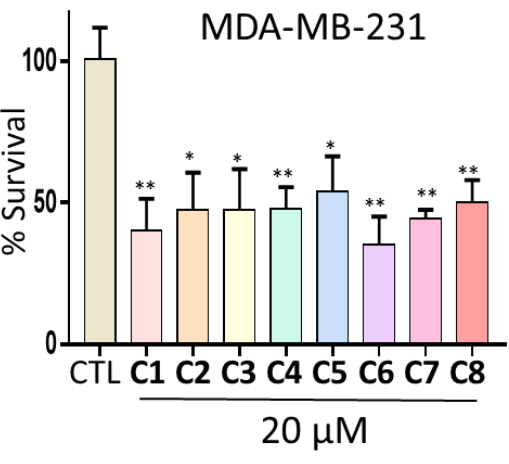

F

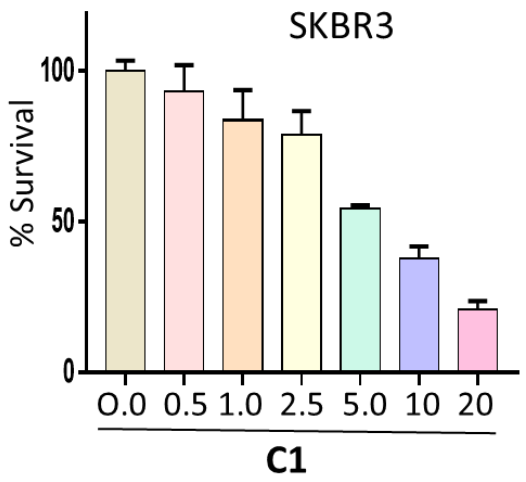


Fig. 4 C1-C8 suppressed metastatic breast cancer cells growth; (A-C) MCF-7, MDA-MB-231 and SKBR3 cells were treated with $20 \mu \mathrm{M}$ of C1-C8 for $48 \mathrm{~h}$ and cell viability was determined in percentage. CTL represented DMSO treatment. Data represents $\pm \mathrm{SD}$ of three independent experiments. Student $\mathrm{t}$ test $* \mathrm{p}<0.05 ; * * \mathrm{p}<0.005 ; * * \mathrm{p}<0.0005$. (D-F) MCF-7, MDAMB-231 and SKBR3 cells were treated with $0,0.5,1,2.5,5,10$ or $20 \mu \mathrm{M}$ of $\mathbf{C} 1$ for $48 \mathrm{~h}$ and cell viability was determined in percentage. . Data represents \pm SD of three independent experiments. Student $t$ test $* p<0.05 ; * * p<0.005 ; * * * p<0.0005$.

\subsubsection{Comparative study with market available anticancer drugs}

Next, we compared the cytotoxic potentials of reference complexes $(\mathbf{C 1}, \mathbf{C 3}$ and $\mathbf{C 7})$ to cisplatin, oxaliplatin and 5 fluro uracil (5-FU) in breast cancer cells (Fig. 5A-C). Interestingly, we observed much stronger cytotoxic effect of these complexes on MCF-7 and MDA-MB-231 AND SKBR33 breast cancer cells as compared to oxaliplatin and 5-FU. Importantly, we observed much better comparative MTT data in SKBR3 cells, where the inhibitory effect of $\mathbf{C 1}, \mathbf{C} 3$ and $\mathbf{C 7}$ was much stronger than oxaliplatin and 5FU. SKBR3 cells are HER-2 oncogene enriched and showing high amplification of HER-2 to promote breast cancer cells growth, survival, invasion and metastasis. Therefore, these complexes could be potential antineoplastic agents to treat these molecular subtypes of breast cancer.

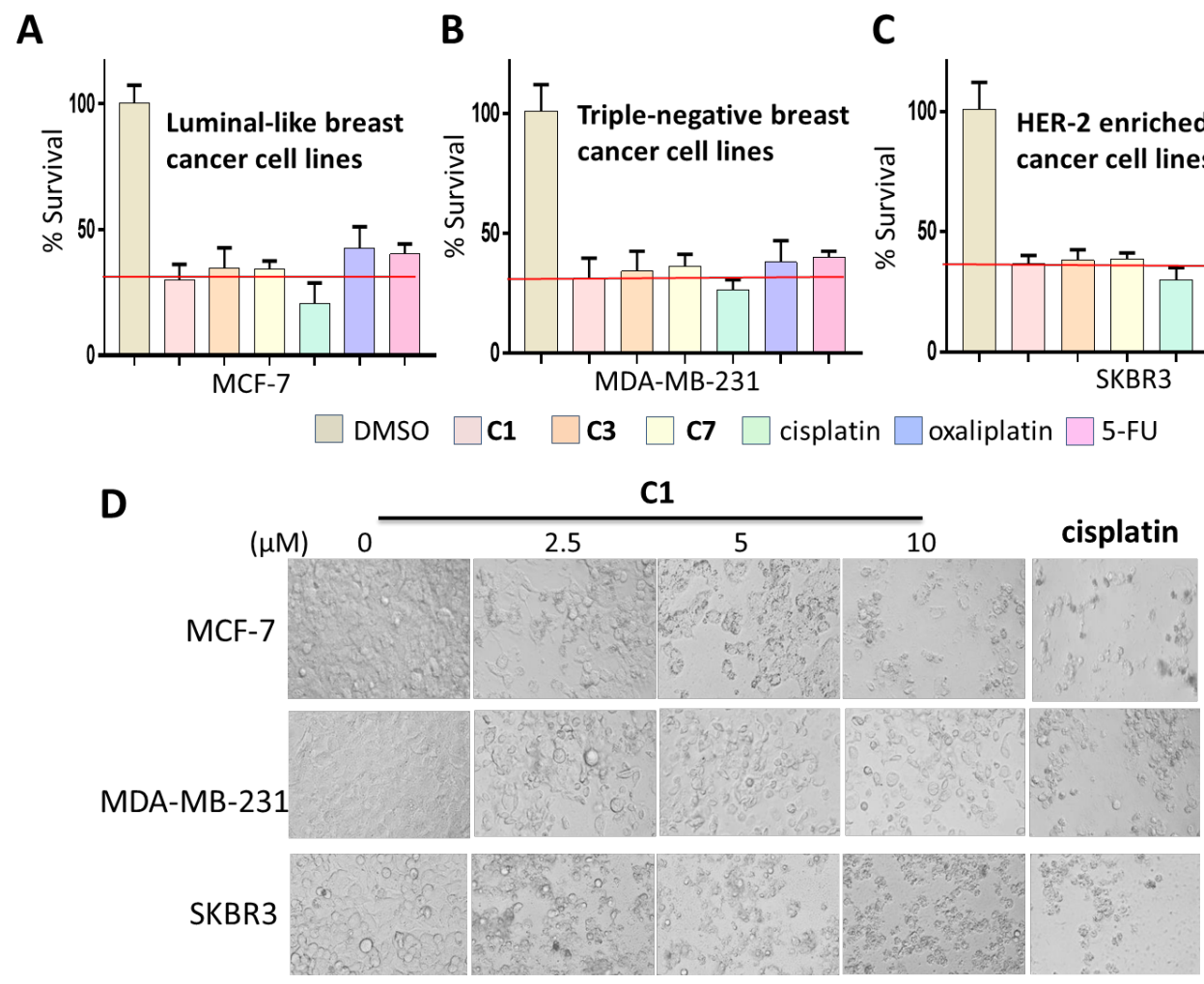

Fig. 5 Comparison anticancer effect of C1, C3 and C7 with anticancer drugs; (A-C) MCF-7, MDA-MB-231 and SKBR3 breast cancer cells were treated with $20 \mu \mathrm{M}$ of $\mathbf{C 1}, \mathbf{C 3}, \mathbf{C 7}$, cisplatin, oxaliplatin or 5-flouro uracil (5-FU) for $48 \mathrm{~h}$ and cell viability was determined in percentage. CTL represents DMSO treated cells. Data represented \pm SD of three independent experiments. (D) 
MCF-7, MDA-MB-231 and SKBR3 cells were treated with DMSO, 2.5, 5 or $10 \mu \mathrm{M}$ of $\mathbf{C 1}$ and $10 \mu \mathrm{M}$ of cisplatin for $48 \mathrm{~h}$ and bright field images were taken to observe cell morphology.

Next, we treated MCF-7, MDA-MB-231 and SKBR33 cells with DMSO, or different concentrations (0.5, 2.5 or $5 \mu \mathrm{M}$ ) of $\mathbf{C 1}$ to detect morphological changes in these cell lines (Fig. 5D). Data suggested that 5 $\mu \mathrm{M}$ of $\mathbf{C 1}$ effectively changed cell morphology of MCF-7, MDA-MB-231 and SKBR33 breast cancer cells in comparison to the control cells. Much more rounded morphology was observed in $\mathbf{C 1}$ treated cells which suggested apoptotic cell death.

\subsubsection{Effect on clonogenic potential of different molecular subtypes of breast cancer}

Clonogenic potential of cancer cells contribute to drug resistance, cancer cell survival and metastasis. Breast cancer cells have potential to form colonies to contribute to chemo resistance. Therefore, we tested the effect of selected complexes on clonogenic potential of MCF-7, MDA-MB-231 and SKBR3 breast cancer cells (Fig. 6A-C). Cancer cells were treated with DMSO, 0.5, 2.5, or $5 \mu \mathrm{M}$ of each $\mathbf{C 1}, \mathbf{C 3}$ or $\mathbf{C 7}$ for 9 days to determine clonogenic potential of these cell lines. Results showed that 2.5 and $5 \mu \mathrm{M}$ of $\mathbf{C 1}$, C3 and C7 suppressed the clonogenic growth of these breast cancer cells. Taken together, these complexes have the ability to inhibit clonogenic potential of different molecular subtypes of breast cancer. 

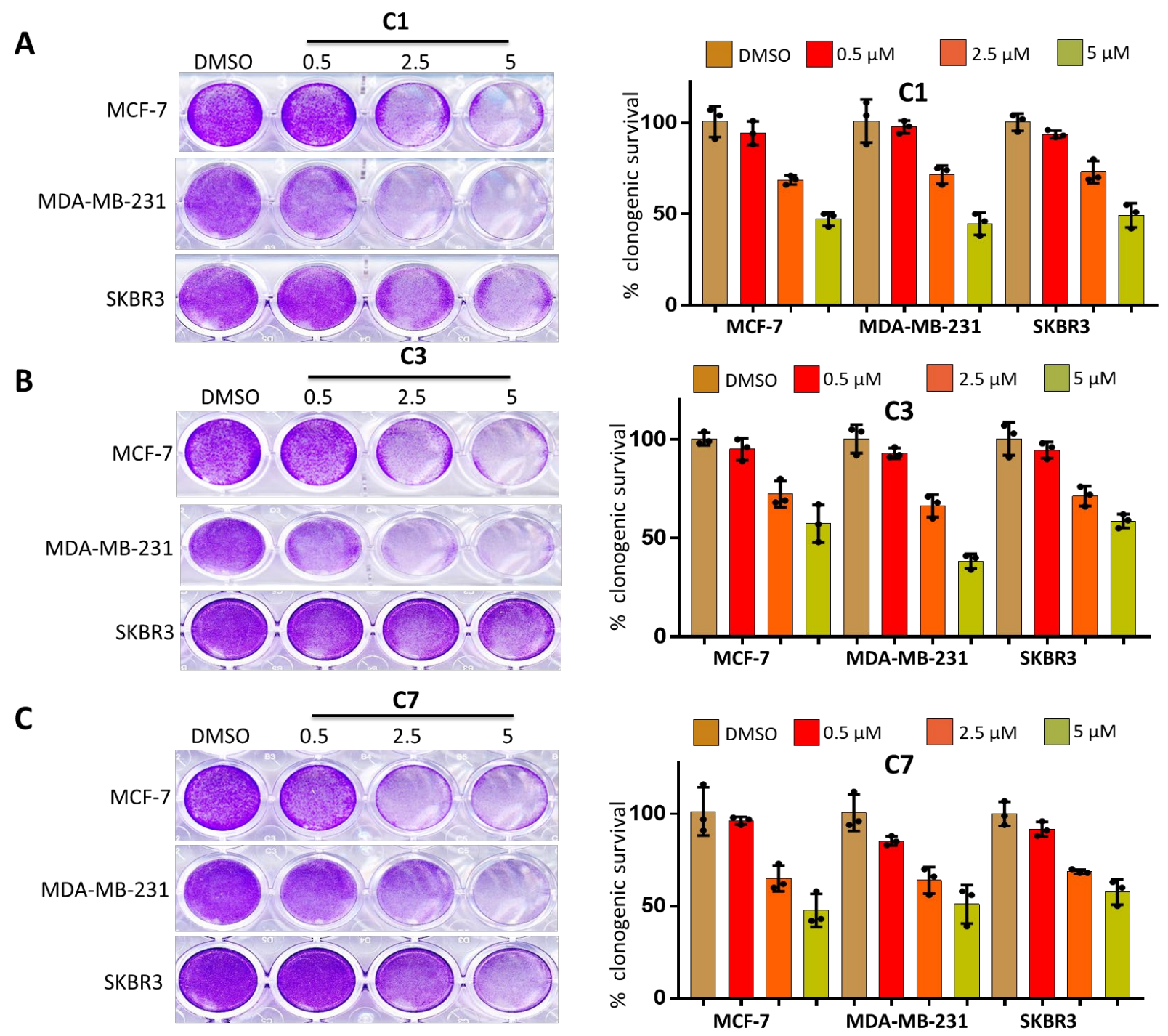

Fig. 6 Effect of C1, C3 and C7 on clonogenic potential of metastatic breast cancer cells; (A-C) MCF-7, MDA-MB-231 and SKBR3 cells were treated with DMSO, 0.5, 2.5 or $5 \mu \mathrm{M}$ of $\mathbf{C 1 ,} \mathbf{C 3}$ or $\mathbf{C 7}$ for 9 days and clonogenic potential was determined using crystal violet staining assay. Color intensity reflected cell viability.

\subsubsection{Novel complexes induced cell death}

Next we investigated the effect of these complexes on cell death of different molecular subtypes of breast cancer. MCF-7, MDA-MB-231 and SKBR3 cells were treated with DMSO, C1, C3 and C7 (10 $\mu \mathrm{M})$ for $48 \mathrm{~h}$ and then TUNEL assay was performed to detect cell death (Fig. 7). C1 and $\mathbf{C 3}$ indicated strong cell death in MDA-MB-231 as compared to $\mathbf{C 7}$, however; there was a clear indication of cell death in MDAMB-231 cells by these three complexes as compared to control cells treated with DMSO. MCF-7 cells showed significant cell death upon treatment with these complexes in comparison to control cells. SKBR3 cells showed higher cell death upon treatment with $\mathbf{C 1}$ as compared to $\mathbf{C} \mathbf{3}$ and $\mathbf{C 7}$ but overall cell death 
induced by these complexes in SKBR3 cells was much higher than the control cells. Taken together, these results suggested that these complexes have potential to induce cell death in different molecular subtypes of breast cancer, which points towards their importance in breast cancer therapies.

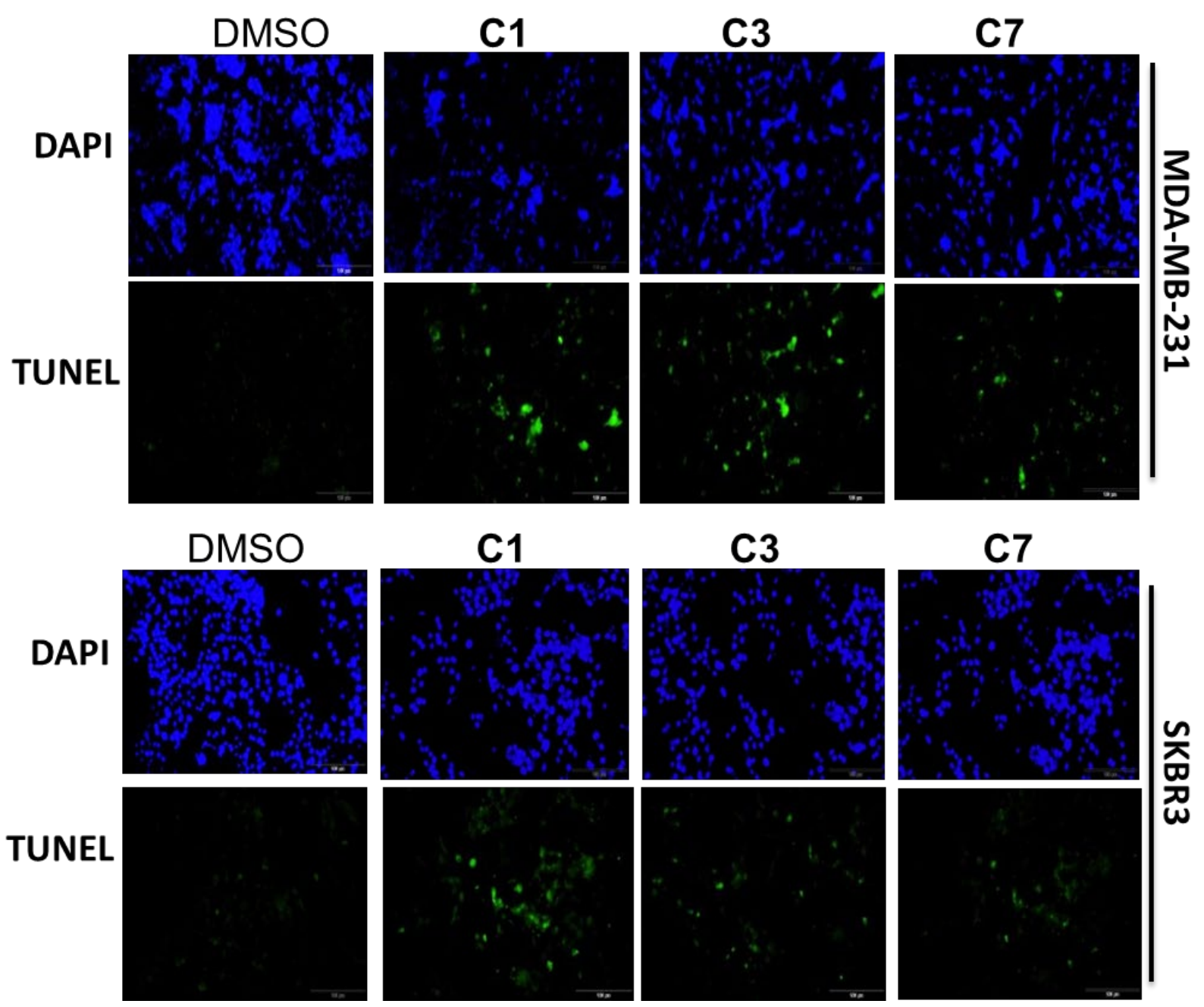

Fig. 7 Novel complexes induced cell death in breast cancer cells; MCF-7, MDA-MB-231 and SKBR3 cells were treated with DMSO, C1, C3 and C7 $(10 \mu \mathrm{M})$ for $48 \mathrm{~h}$ and TUNEL assay was performed to detect cell death. Apoptosis was higher in MCF-7, MDA-MB-231 and SKBR3 cells treated with these complexes as compared to cells treated with DMSO.

\subsubsection{Suppression of cancer stem cells formation and induction of cellular senescence}

Cancer stem cells play important role in cancer progression and chemoresistance. Therefore, inhibition of cancer stem cells formation is considered as an important mechanism to suppress cancer progression. We tested the effect of Pt complexes on mammopshere formation/breast cancer stem cells formation. MCF-7, MDA-MB-231 and SKBR3 cells were grown as mammopshere/ cancer stem cells and then treated with C1, C3 and $\mathbf{C} 7(10 \mu \mathrm{M})$ for 7 days and their effect on cancer stem cells formation was analyzed (Fig. 8A). Mammosphere formation assay showed that effect of $\mathbf{C 1}$ was much stronger on stem cells formation 
as compared to $\mathbf{C 3}$. These results suggested stronger ability of $\mathbf{C 1}, \mathbf{C} 3$ and $\mathbf{C 7}$ to suppress breast cancer stem cells formation and thereby decrease cancer progression.

Cellular senescence is also considered important mechanisms to retard cancer cell growth and thereby decreasing cancer progression and invasion. Therefore we targeted cellular senescence mechanism to see breast cancer progression. MDA-MB-231 and SKBR3 cells were treated with $\mathbf{C 1}, \mathbf{C 3}$ and $\mathbf{C 7}(10 \mu \mathrm{M})$ for 5 days and cellular senescence was determined using senescence-associated beta-galactosidase assay (Fig. 8B). Importantly, we observed more senescent cells in MDA-MB-231 and SKBR3 cells treated with these complexes in comparison to the control cells. These results suggested potentials of these complexes to promote cellular senescence, retard cancer cell growth and thereby suppress cancer progression.

A

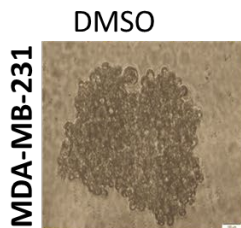

C1
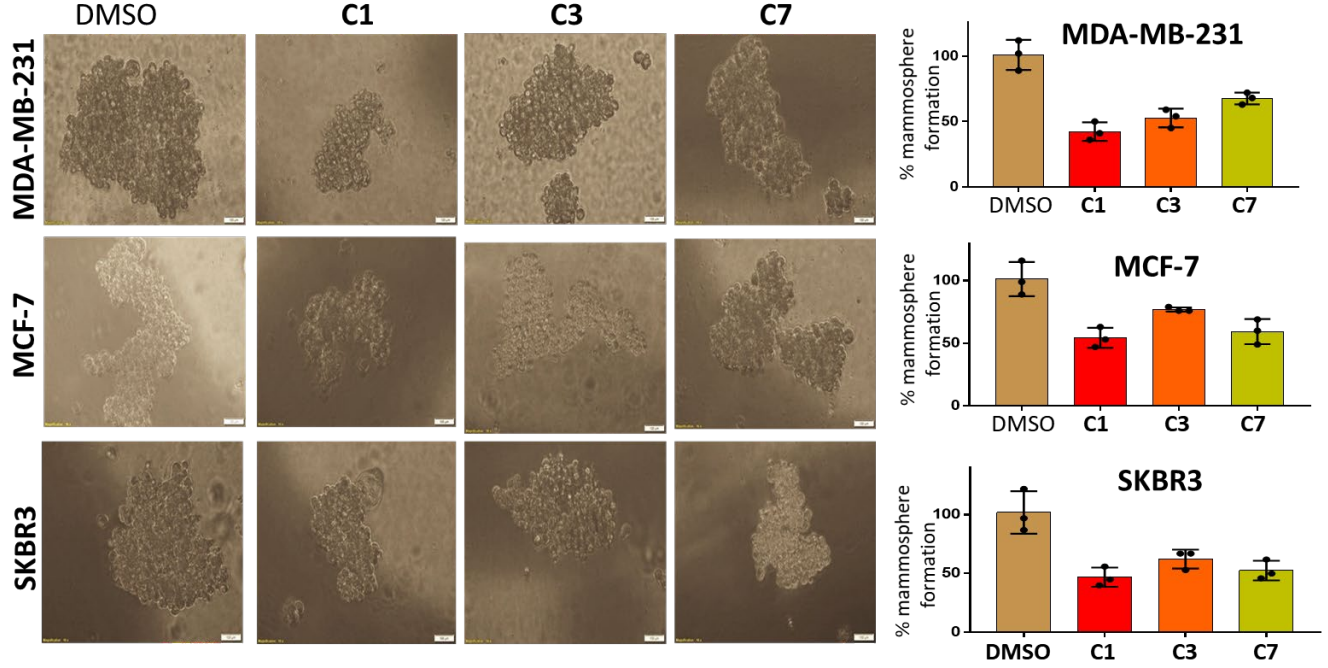

B

DMSO

C1

C3

C7

MDA-MB-231

MCF-7

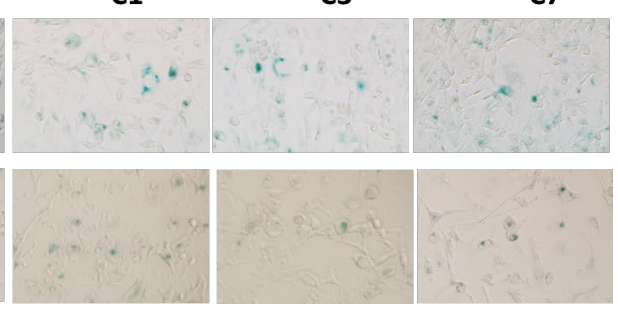

Fig. 8 Novel complexes suppress cancer stem cells formation and induce cellular senescence; (A) MCF-7, MDA-MB-231 and SKBR3 cells were grown as mammosphere/cancer stem cells and then treated with $\mathbf{C 1}, \mathbf{C} 3$ and $\mathbf{C} 7$ (10 $\mu \mathrm{M})$ for 7 days to determine their effect on cancer stem cells formation. Data represented inhibition in mammopshere formation by treatment with C1, C3 and C7 treatment in comparison to control group. (B) MCF-7, MDA-MB-231 and SKBR3 cells were treated with C1, C3 and $\mathbf{C 7}(10 \mu \mathrm{M})$ for 5 days to determine cellular senescence using beta-galactosidase assay. Greenish color represented senescent cells. 


\subsubsection{Effect on breast cancer cells migration}

Cancer cell migration plays a critical role in invasion and metastasis, inhibition of cancer cell migration is associated with suppression of cancer progression. Therefore, we investigated the effect of these platinum complexes on breast cancer cell migration. MDA-MB-231 and SKBR3 cells were treated with selected complexes $(10 \mu \mathrm{M})$ for 2 days and wound healing area/migrated cells in gap were determined after $24 \mathrm{~h}$ performing wound/scratch at $0 \mathrm{~h}$. Wound healing assay showed that MDA-MB-231 and SKBR3 cells treated with $\mathbf{C 1}, \mathbf{C} 3$ and $\mathbf{C 7}$ migrated much slower as compared to the control cells (Fig. 9A-B). These results suggested $\mathbf{C 1}, \mathbf{C} \mathbf{3}$ and $\mathbf{C} 7$ strong potentials to suppress breast cancer cell migration and thereby inhibit breast cancer progression.
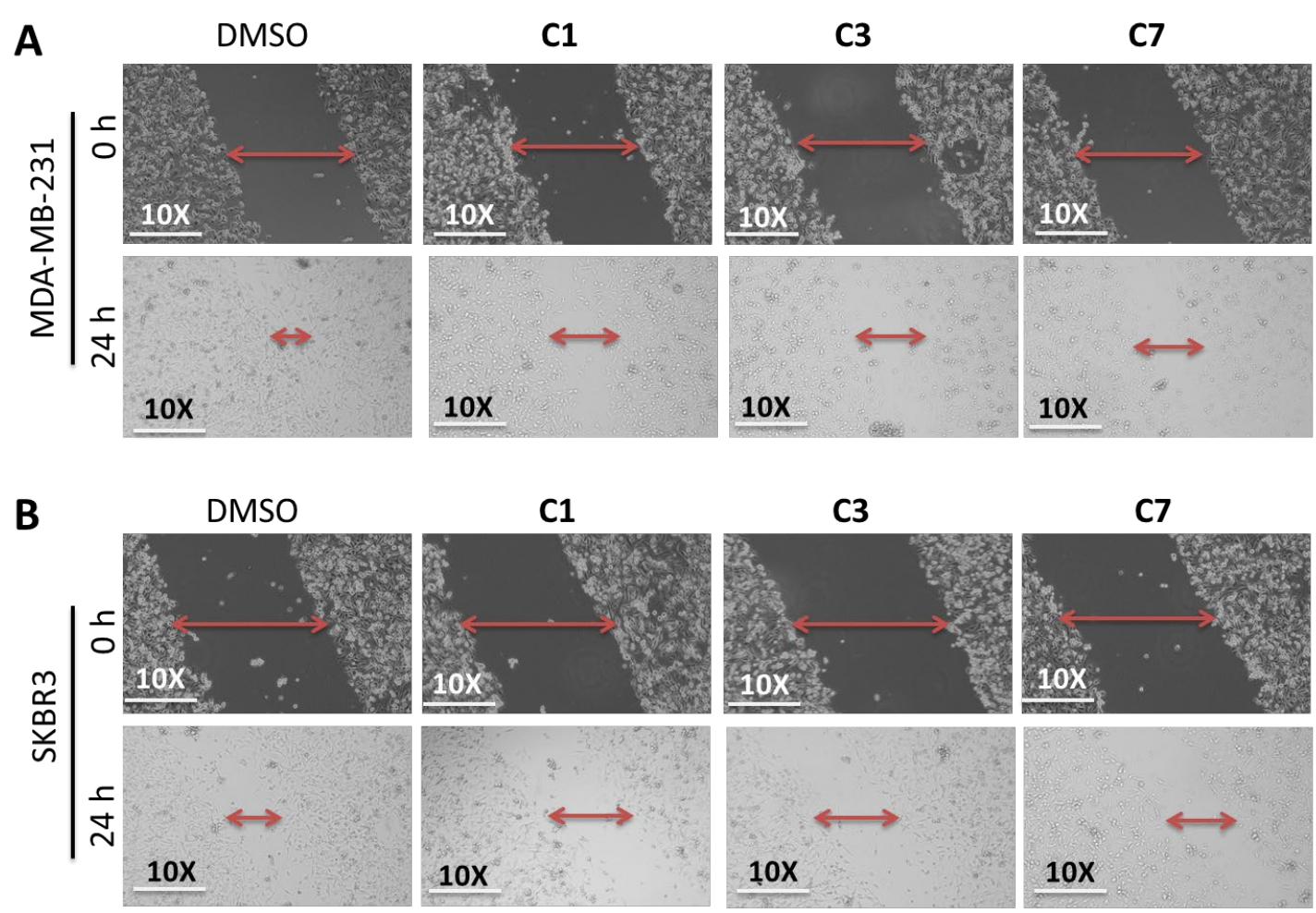

Fig. 9 Pt complexes suppressed migration of metastatic breast cancer cells; (A-B) MDA-MB-231 and SKBR3 cells were treated with $\mathbf{C 1}, \mathbf{C} 3$ and $\mathbf{C 7}(10 \mu \mathrm{M})$ for 2 days and wound healing area/migrated cells in gap were determined after $24 \mathrm{~h}$ after performing wound/scratch at $0 \mathrm{~h}$ (Magnification 10X).

2.2.7. Pt(II) complexes induced DNA damage and autophagy and suppressed BCL2/cyclinD1 expressions

DNA damage is one of the critical step to trigger cell death signaling pathway. Therefore, we investigated the effect of $\mathbf{C 1}, \mathbf{C} 3$ and $\mathbf{C 7}$ on pH2AX a DNA damage marker expression. MDA-MB-231 and SKBR3 breast cancer cell were treated with $20 \mu \mathrm{M}$ of $\mathbf{C 1}, \mathbf{C} 3$ or $\mathbf{C 7}$ for 2 days and DNA damage marker p-H2AX 
expression was determined by western blot (Fig. 10A-B). Western blot data showed strong induction of DNA damage marker p-H2AX expression in cancer cells treated with mentioned complexes as compared to control cells.

Cyclin-D1 is one of the aggressive oncogene that plays crucial role in cancer progression by increasing DNA content and cell cycle progression. Therefore, we investigated the effect of these complexes on cyclin-D1 expression. MDA-MB-231 and SKBR3 cells were treated with $20 \mu \mathrm{M}$ of $\mathbf{C 1}, \mathbf{C 3}$ and $\mathbf{C 7}$ for 2 days and cell cycle progression marker cyclin-D1 expression was determined by western blot (Fig. 10CD). Western blot data showed inhibition of cyclin-D1 expression in cells treated with each Pt(II) complex as compared to control cells. Importantly, the inhibition of cyclin-D1 expression by $\mathbf{C} 1$ was much stronger in both MDA-MB-231 and SKBR3 cells which suggested the importance of $\mathbf{C} 1$ in breast cancer cells.

Autophagy is a critical mechanism that suppresses cancer progression and induction of autophagy has been linked with the inhibition of cancer metastasis. MDA-MB-231 cells were treated with 5, 10 or 20 $\mu \mathrm{M}$ of $\mathbf{C} 1$ for 2 days and autophagy markers ATG3 and LC3B expressions were determined by western blot (Fig. 10E). Our data suggested dose-dependent induction of both ATG3 and LC3B expressions, these markers of autophagy induction were significantly up regulated in $\mathbf{C} \mathbf{1}$ treated cells. These results suggested that $\mathbf{C} \mathbf{1}$ has the ability to induce autophagy and thereby suppress breast cancer progression.

Anti-apoptotic signaling pathway also contributes to drug resistance and cancer progression. We investigated the effect of $\mathbf{C 1}$ on BCL2 expression that is an anti-apoptotic gene that promote cancer cell growth by preventing cancer cell death. MDA-MB-231 cells were treated with 5, 10 and $20 \mu \mathrm{M}$ of $\mathbf{C 1}$ for 2 days and an anti-apoptotic marker BCL2 expression was determined by western blot (Fig. 10F). Our results showed strong inhibition of BCL2 expression when treated with different doses of C1. These results suggested ability of $\mathbf{C 1}$ to suppress BCL2 gene expression and thereby promoted cancer cell death. Next, we investigated the effect of $\mathbf{C 1}$ on BAX protein induction that positively correlates with apoptosis. Results indicated that $\mathbf{C 1}$ up-regulated BAX expression in dose-dependent manner in MDA-MB-231 cell lines to induce apoptosis (Fig. 10G). 

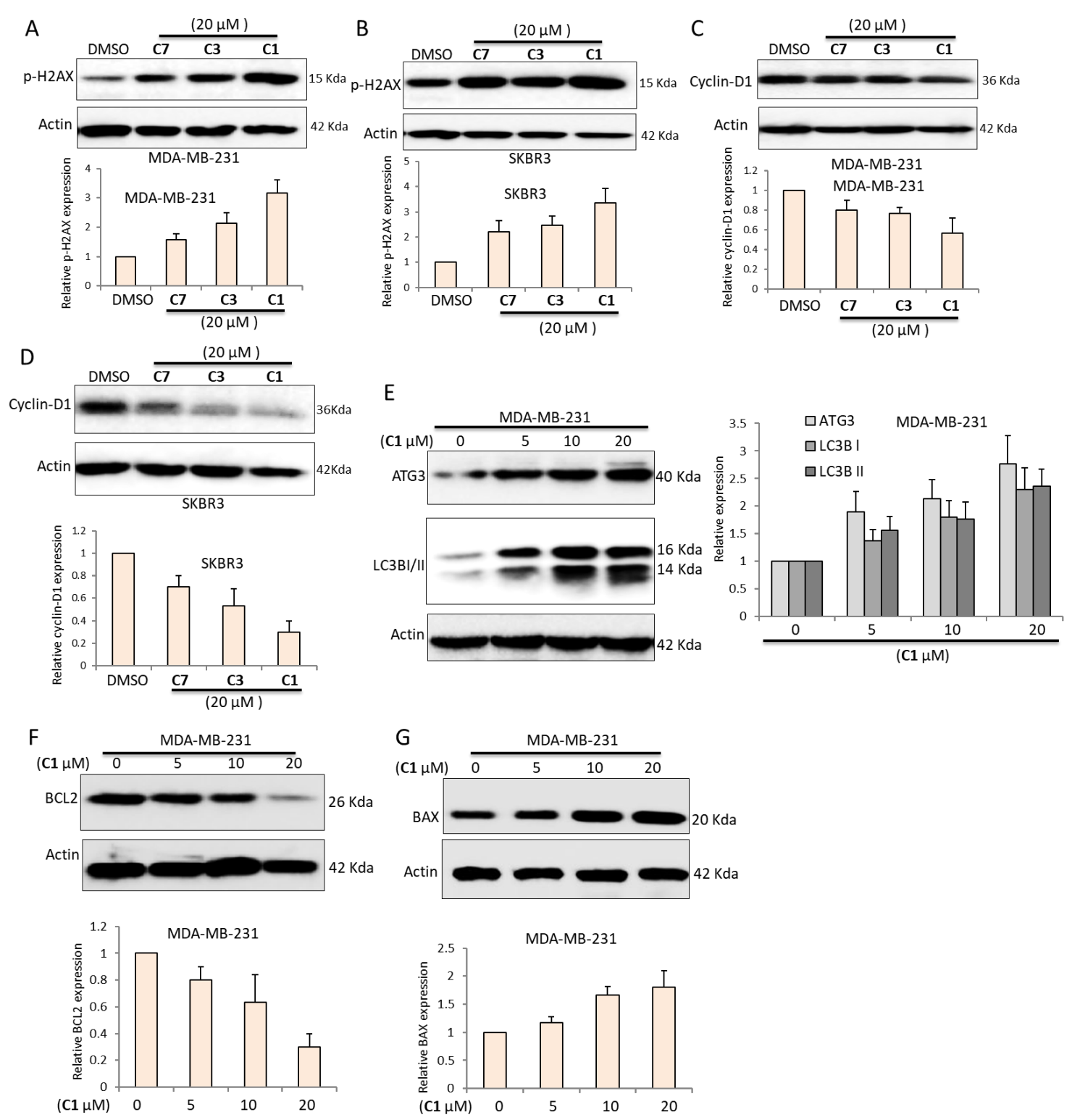

Fig. 10 Pt complexes targeted different oncogenic and tumor suppressor proteins to control breast cancer cell growth; (A-B) MDA-MB-231 and SKBR3 cells were treated with mentioned complexes $(20 \mu \mathrm{M})$ for 2 days and DNA damage marker p-H2AX expression was determined by western blot. (C and D) MDA-MB-231 and SKBR3 cells were treated with C1, C3 or C7 (20 $\mu$ M) for 2 days and cell cycle progression marker cyclin-D1 expression was determined by western blot. (E) MDA-MB-231 cells were treated with 5, 10 or $20 \mu \mathrm{M}$ of $\mathbf{C 1}$ for 2 days and autophagy markers ATG3 and LC3B expressions were determined by western blot. (F) MDA-MB-231 cells were treated with 5, 10 or $20 \mu \mathrm{M}$ of $\mathbf{C 1}$ for 2 days and anti-apoptotic marker BCL2 expressions was determined by western blot. Actin was used as a loading control in all these analysis, (G) MDA-MB-231 cells were treated with 5, 10 or $20 \mu \mathrm{M}$ of $\mathbf{C 1}$ for 2 days and apoptosis induction marker BAX expression was determined by western blot. Actin was used as a loading control. 

expressions

Cancer cell metabolism mainly glycolysis play crucial role in cancer progression by providing ATP to cancer cells for growth and proliferation. Both pyruvate kinase isozyme (PKM) and lactate dehydrogenase (LDHA) play important roles to regulate glycolysis. Inhibition of these PKM and LDHA has been linked with decrease cell growth, survival and metastasis. The effect of these complexes was investigated on PKM and LDHA glycolytic genes. MDA-MB-231 cells were treated with selected complexes (C1, C3 and $\mathbf{C} 7)(20 \mu \mathrm{M})$ for 2 days and glycolysis marker pyruvate kinase isozyme (PKM) expression was determined by western blot (Fig. 11A). Interestingly, we observed strong inhibition in PKM expression in cells treated with $\mathbf{C} \mathbf{1}$ as compared to $\mathbf{C} \mathbf{3}$ and $\mathbf{C} 7$, however, the effect of $\mathbf{C} 7$ was much more prominent. Next, we treated MDA-MB-231 cells with 5, 10 or $20 \mu \mathrm{M}$ of $\mathbf{C 1}$ for 2 days and glycolysis marker pyruvate kinase isozyme (PKM) expression was determined by western blot (Fig. 11B). Results showed dose-dependent inhibition of PKM expression in response to C1. Next, we treated MDAMB-231 cells with 5,10 or $20 \mu \mathrm{M}$ of $\mathbf{C 1}$ for 2 days and glycolysis marker lactate dehydrogenase (LDHA) expression was determined by western blot (Fig. 11C). These results showed C1 reduced LDHA expression in a dose-dependent-manner. These results suggested that $\mathbf{C} 1$ has the ability to suppress PKM and LDHA expression and thereby decrease the production of ATP to inhibit cancer cell growth.

Based on these results both $\mathbf{C 1}$ and $\mathbf{C} 7$ suppressed glycolytic genes expression, we performed ATP production assay. MDA-MB-231 cells were treated with $\mathbf{C} 1$ and $\mathbf{C} 7(20 \mu \mathrm{M})$ for 2 days and cellular ATP production was determined in percentage using ATP production kit (Fig. 11D). Data suggested less ATP production in MDA-MB-231 cells treated with $\mathbf{C 1}$ and $\mathbf{C} 7$ in comparison to control group treated with DMSO. Taken together, these results suggested that both $\mathbf{C 1}$ and $\mathbf{C} 7$ have potentials to decrease ATP production by targeting PKM and LDHA expressions. 
A
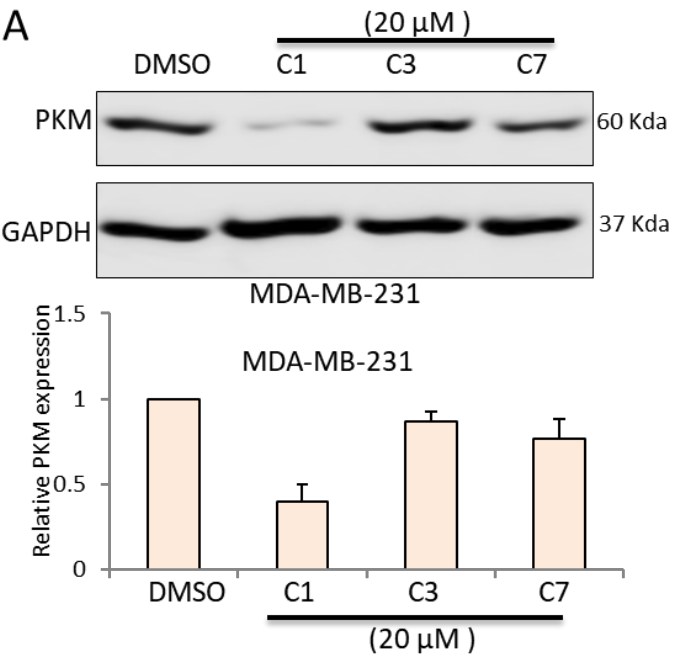

C
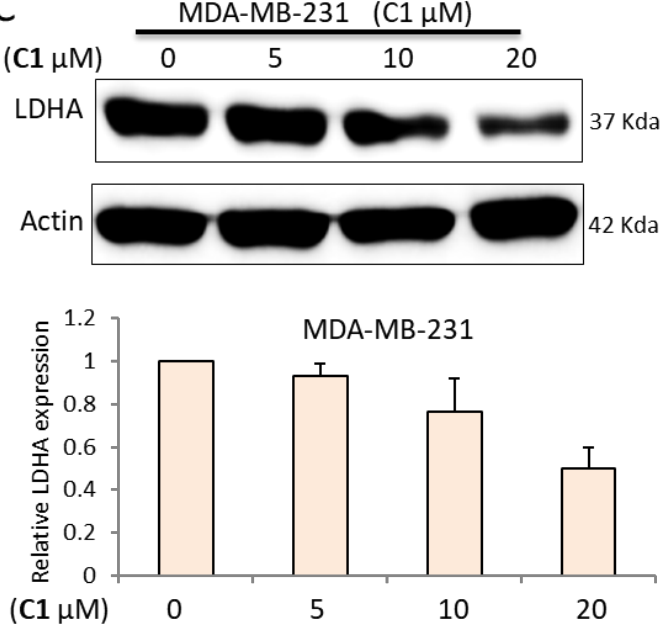

B
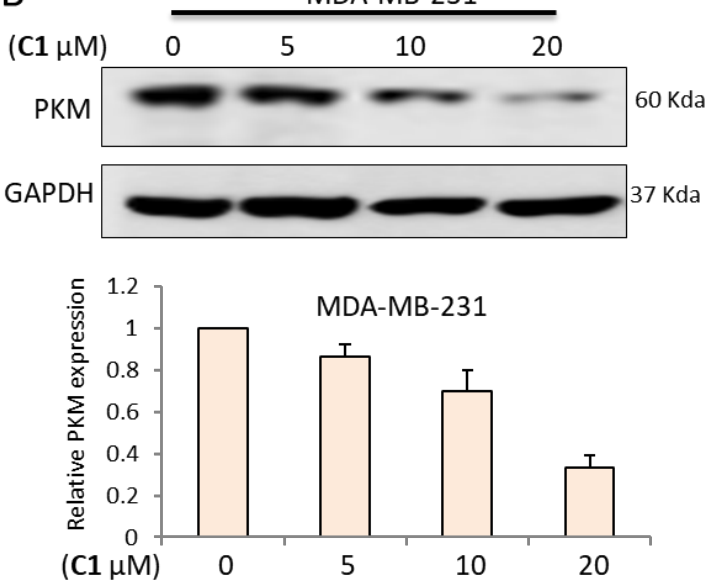

D

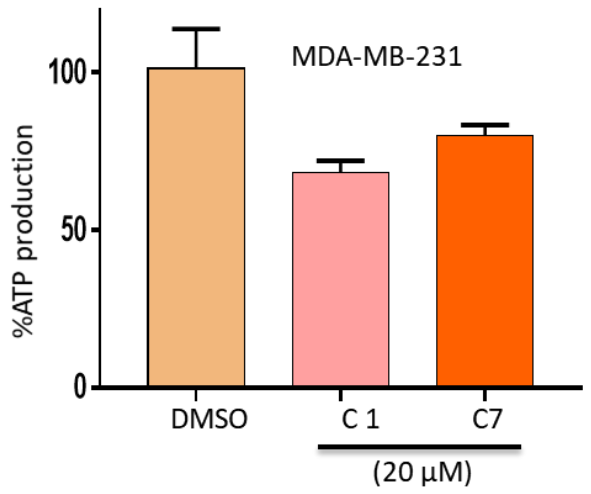

Fig. 11 Platinum complexes targeted cancer cell metabolism and glycolysis to control cell growth; (A) MDA-MB-231 cells were treated with $\mathbf{C 1}, \mathbf{C} 3$ or $\mathbf{C} 7(20 \mu \mathrm{M})$ for 2 days and glycolysis marker Pyruvate kinase isozyme (PKM) expression was determined by western blot. GAPDH was used as a loading control. (B) MDA-MB-231 cells were treated with 5, 10 or $20 \mu \mathrm{M}$ of $\mathbf{C 1}$ for 2 days and glycolysis marker pyruvate kinase isozyme (PKM) expression was determined by western blot. GAPDH was used as a loading control. (C) MDA-MB-231 cells were treated with 5, 10 or $20 \mu \mathrm{M}$ of $\mathbf{C 1}$ for 2 days and glycolysis marker lactate dehydrogenase (LDHA) expression was determined by western blot. Actin was used as a loading control. (D) MDA-MB-231 cells were treated with $\mathbf{C} 1$ and $\mathbf{C} 7(20 \mu \mathrm{M})$ for 2 days and cellular ATP production was determined in percentage using ATP production kit. Data suggest less ATP production in $\mathbf{C 1}$ and $\mathbf{C} 7$ treated MDA-MB-231 cells as compared to control group treated with DMSO.

\section{Discussion}

The development of new platinum based anticancer drug is an active field because platinum based anticancer drugs are among the most effective chemotherapeutic candidates. The current market available 
platinum drugs suffer from several limitations including multiple side effects, working in some cancer but inactive in others and resistance that may be intrinsic or acquired during the exposure time. The design and synthesis of new platinum complexes with new assemblies will overcome some of these limitations and will strengthen the fight against cancer. We synthesized C1-C8 and preliminary analyzed them for their in vitro anticancer activities in hope to provide bases for the future developments. We used simple procedures for their synthesis from readily available precursors. Similarly all the compounds were isolated in high yields and purity form the reaction mixtures without any laborious column chromatography. All these complexes were characterized thoroughly by NMR methods, ESI MS and three complexes were structurally characterized by single crystal X-ray analysis. A series of structurally functionalized complexes were prepared that showed their reproducible synthesis. Similarly, these slight structural modifications also showed effect on their anticancer properties. The solubility of a particular drug in water is also crucial; though C1-C8 are not soluble in water but their anticancer effect is very good. Some water-soluble functions like $-\mathrm{COONa},-\mathrm{SO}_{3} \mathrm{Na}$ or alkyl ammonium function could be added to the organic part of these complexes that could make them good water-soluble and more biocompatible. Another approach could be the replacement of ancillary chloride with a coordinating co-ligand and making ionic complexes with chloride, nitrate, tetrafluoroborate etc. anions, we worked on the later approach that is under submission for publication.

Breast cancer is aggressive in nature especially TNBC and HER-2 enriched subtypes of breast cancer are highly metastatic in nature. Due to metastatic potential TNBC and HER-2 positive breast cancer are challenging to treat effectively. Chemotherapy is still considered the important option for breast cancer. Due to amplification of oncogenic signaling pathways and loss of function of tumor suppressor proteins, it is challenging to treat TNBC. [48] Moreover, HER-2 amplification also activate several growth factor signaling pathways that contribute to cancer cell survival and thereby promoting cancer invasion, migration and metastasis. [42] Importantly, drug resistance is common in these subtypes of breast cancers due to metastatic tumor environment. Therefore, anticancer agents that can target TNBC and HER-2 enriched breast cancers are considered important in the field of breast cancer research and required on urgent basis for better treatment of patients.

Here, we synthesized Pt(II) complexes those showed inhibition of cell growth of different molecular subtypes of breast cancer including luminal-like, TNBC and HER-2 enriched. We have compared these complexes with cisplatin, oxaliplatin and 5-FU. MTT assay of selected complexes from the list showed the activity of $\mathbf{C 1}, \mathbf{C} \mathbf{3}$ and $\mathbf{C 7}$ was near to cisplatin but the activity of these complexes was much more prominent as compared to oxaliplatin and 5-FU. Moreover, these complexes suppressed the clonogenic potential of different molecular subtypes of breast cancer, thus suggesting a role in suppression of breast 
cancer cells growth. These complexes showed the ability to suppress the formation of cancer stem cells/mammospheres. Cancer stem cells play important role in cancer initiation [49], therefore decrease formation of cancer stem cells by these complexes pointed towards the importance of these complexes in the field of translational cancer research.

Our results also indicated inhibition of cell migration induced by these complexes, which suggested their roles in suppression of cancer invasion and metastasis. The induction of cellular senescence in TNBC and HER-2 enriched breast cancer cells, suggested a role in cell retardation. Mechanistically, these complexes suppressed BCL-2 and Cyclin-D1 expression; both are critical oncogenes and required for cancer cell survival and cell cycle progression respectively. Thus inhibition of cell migration, induction of cellular senescence and regulation of BCL-2/Cyclin-D1 expression by these complexes suggested their diverse roles in targeting TNBC and HER-2 positive breast cancer.

We found DNA damage signaling pathway by activating $\mathrm{pH} 2 \mathrm{AX}$ expression and promoted cell death induced by these complexes. We also observed regulation of autophagy markers ATG3 and LC3B in cancer cells in response to treatment with these complexes. Western blot data suggested increase expression of ATG3 and LC3B, thus suggesting a role in activation of autophagy and hence promotion of cell death. Importantly, activation of both DNA damage signaling pathway and autophagy in TNBC and HER-2 positive breast cancer suggested suppression of these types of breast cancer.

Cancer cell metabolism plays a vital role in the production of ATP via glycolysis and this ATP is used by cancer cells for growth and proliferation. Importantly, we found suppressed expression of PKM and LDHA, key glycolytic enzymes those are required for glycolysis. Breast cancer cells treated with these complexes showed inhibition in PKM and LDHA expressions, thus suggested their potentials in cancer cell metabolism. Moreover, they decreased the production of ATP that is required for cancer cell growth, proliferation and invasion. Overall, these results highlighted a diverse role of C1-C8 in breast cancer cells mainly in TNBC and HER-2 positive breast cancer, those have limited chemotherapeutic options. These complexes triggered DNA damage and autophagy on one side and suppressed cancer cell metabolism and BCL2/Cyclin-D1 expressions on the other side, thus suggesting a critical role in TNBC and HER-2 positive breast cancer cell metabolism. 


\section{Materials and methods}

\subsection{Chemistry}

\subsubsection{General experimental and materials}

All solvents and reagents were purchased from commercial sources. $\mathrm{K}_{2} \mathrm{PtCl}_{4}$ was purchased from LeYan Chemical Company China. NMR spectroscopic analyses were conducted on Bruker AVANCE 400 or $500 \mathrm{MHz}$ spectrometer at $298 \mathrm{~K}$ in DMSO- $d_{6}, \mathrm{CDCl}_{3}$ or $\mathrm{D}_{2} \mathrm{O}$. HR-ESI-MS spectra were acquired using waters G2-Xs QTof mass spectrometer. Crystal data was collected at $100 \mathrm{~K}$ on a Rigaku Oxford Diffraction Supernova Dual Source, $\mathrm{Cu}$ at Zero equipped with an AtlasS2 CCD using $\mathrm{Cu} \mathrm{K} \alpha$ radiation. The data were collected and processed using Oxford Diffraction, Xcalibur CCD System. CrysAlisPro. Oxford Diffraction Ltd: Abingdon, England, UK, 201024. The structures were solved by direct methods using Olex2 software [50] and the non-hydrogen atoms were located from the trial structure and then refined anisotropically with SHELXL-2018 [51] using a full-matrix least squares procedure based on $F^{2}$. The weighted $R$ factor, $w R$ and goodness-of-fit $S$ values were obtained based on $F^{2}$.The hydrogen atom positions were fixed geometrically at the calculated distances and allowed to ride on their parent atoms. Crystallographic data of each complex was submitted to Cambridge crystallographic data center under the number, CCDC 2067803-2067805, that can be obtained free of charge from the platform at e-mail: deposit@ccdc.cam.ac.uk, tel: +44-1223336408 and fax: +44-1223336003.

\subsubsection{Synthesis of ligands (L1-L8)}

$10 \mathrm{mmol}$ of 2-(phenylthio)aniline was dissolved in $40 \mathrm{~mL}$ of ethanol, $10 \mathrm{mmol}$ of substituted salicylaldehyde was added to it and the mixture was heated and stirred at reflux till completion (checked by TLC). After completion the reaction mixture was cooled in refrigerator overnight to solidify the ligand, that was filtered while cold and washed further with $10 \mathrm{~mL}$ of cold ethanol. It was recrystallized from ethanol where ever needed by dissolving it at high temperature and cooling in refrigerator overnight. Each ligand was obtained in good to excellent yield and characterized by analytical techniques, the data were given below and instrumental figures are given in the supplementary data.

L1 Yield and spectroscopic analyses results were similar as reported previously. [52]

L2; Yellow solid in 76\% isolated yield. ${ }^{1} \mathrm{H}$ NMR (400 MHz, DMSO- $\left.d_{6}\right) \delta 12.64(\mathrm{~s}, 1 \mathrm{H}), 8.86(\mathrm{~s}, 1 \mathrm{H})$, $7.48(\mathrm{~d}, J=7.8 \mathrm{~Hz}, 1 \mathrm{H}), 7.39$ (d, $J=14.2 \mathrm{~Hz}, 7 \mathrm{H}), 7.23(\mathrm{t}, J=7.1 \mathrm{~Hz}, 2 \mathrm{H}), 7.05(\mathrm{~d}, J=7.8 \mathrm{~Hz}, 1 \mathrm{H}), 6.85$ $(\mathrm{d}, J=8.3 \mathrm{~Hz}, 1 \mathrm{H}), 2.25$ (s, 3H) ppm. ${ }^{13} \mathrm{C}$ NMR (100 MHz, DMSO-d $) \delta 163.9,158.6,147.0,134.8$, 
$133.4,133.0,132.4,131.8,130.2,130.1,128.5,128.4,128.1,128.1,119.3,119.1,117.0,20.3$ ppm. HRMS (ESI): Calcd for $\mathrm{C}_{20} \mathrm{H}_{17} \mathrm{NOS}, 319.1031$ : Found: 320.1115, [M+H] $]^{+}$.

L3; Yellow solid in 78\% isolated yield. ${ }^{1} \mathrm{H}$ NMR (400 MHz, DMSO- $\left.d_{6}\right) \delta 12.59(\mathrm{~s}, 1 \mathrm{H}), 8.90(\mathrm{~s}, 1 \mathrm{H})$, $7.54-7.44(\mathrm{~m}, 2 \mathrm{H}), 7.43-7.31(\mathrm{~m}, 6 \mathrm{H}), 7.31-7.21(\mathrm{~m}, 2 \mathrm{H}), 7.07$ (d, $J=7.8 \mathrm{~Hz}, 1 \mathrm{H}), 6.96$ (dd, $J=9.0$, $4.4 \mathrm{~Hz}, 1 \mathrm{H}) \mathrm{ppm} .{ }^{19} \mathrm{~F}$ NMR $\left(376 \mathrm{MHz}, \mathrm{DMSO}-d_{6}\right) \delta-125.08(\mathrm{td}, J=8.5,4.6 \mathrm{~Hz}) \mathrm{ppm} .{ }^{13} \mathrm{C} \mathrm{NMR}(100$ MHz, DMSO- $\left.d_{6}\right) \delta 162.73,162.70,156.92,155.31$ (d, $\left.J=234.7 \mathrm{~Hz}\right), 146.76,133.33,132.43,131.93$, 130.34, 130.16, 128.57, 128.44, 121.02 (d, $J=23.6 \mathrm{~Hz}), 119.84$ (d, $J=7.6 \mathrm{~Hz}), 119.15,118.52$ (d, $J=7.7$ $\mathrm{Hz}), 117.69$ (d, $J=23.4 \mathrm{~Hz})$ ppm. HRMS (ESI): Calcd for $\mathrm{C}_{19} \mathrm{H}_{14} \mathrm{FNOS}, 323.0780$ : Found: 324.0853, $[\mathrm{M}+\mathrm{H}]^{+}$.

L4; Yellow solid in 83\% isolated yield. ${ }^{1} \mathrm{H}$ NMR (500 MHz, Chloroform- $d$ ) $\delta 13.06(\mathrm{~s}, 1 \mathrm{H}), 8.52(\mathrm{~s}, 1 \mathrm{H})$, $7.46-7.41(\mathrm{~m}, 2 \mathrm{H}), 7.38-7.28(\mathrm{~m}, 6 \mathrm{H}), 7.23-7.15(\mathrm{~m}, 3 \mathrm{H}), 7.00(\mathrm{~d}, J=8.7 \mathrm{~Hz}, 1 \mathrm{H}) \mathrm{ppm} .{ }^{13} \mathrm{C}$ NMR $\left(125 \mathrm{MHz}, \mathrm{CDCl}_{3}\right) \delta 161.1,159.7,146.4,133.6,133.1,133.0,132.7,131.3,130.4,129.4,127.9,127.8$, 127.6, 123.6, 120.0, 119.0, 118.0 ppm. HRMS (ESI): Calcd for $\mathrm{C}_{19} \mathrm{H}_{14} \mathrm{ClOS}$, 339.0485: Found: 340.0573., $[\mathrm{M}+\mathrm{H}]^{+}$.

L5; Yellow solid in 87\% isolated yield. ${ }^{1} \mathrm{H}$ NMR (400 MHz, DMSO- $\left.d_{6}\right) \delta 12.89(\mathrm{~s}, 1 \mathrm{H}), 8.91(\mathrm{~s}, 1 \mathrm{H})$, 7.84 (s, 1H), 7.54 (d, $J=8.8 \mathrm{~Hz}, 1 \mathrm{H}), 7.47$ (d, $J=7.9 \mathrm{~Hz}, 1 \mathrm{H}), 7.43-7.30$ (m, 6H), 7.25 (t, $J=7.5 \mathrm{~Hz}$, 1H), $7.08(\mathrm{~d}, J=7.8 \mathrm{~Hz}, 1 \mathrm{H}), 6.93(\mathrm{~d}, J=8.8 \mathrm{~Hz}, 1 \mathrm{H}) \mathrm{ppm} .{ }^{13} \mathrm{C}$ NMR (100 MHz, DMSO-d 6 ) $\delta$ 162.6, $159.7,146.7,136.2,134.7,133.3,132.4,131.9$, 130.4, 130.2, 128.6, 128.5, 128.4, 121.5, 119.6, 119.2 , 110.4 ppm. HRMS (ESI): Calcd for $\mathrm{C}_{19} \mathrm{H}_{14} \mathrm{BrOS}, 382.9979$ : Found: 384.0067, [M+H] ${ }^{+}$.

L6; Yellow solid in 68\% isolated yield. ${ }^{1} \mathrm{H}$ NMR (500 MHz, Chloroform- $d$ ) $\delta 12.65(\mathrm{~s}, 1 \mathrm{H}), 8.56(\mathrm{~s}, 1 \mathrm{H})$, $7.49-7.44$ (m, 2H), 7.39 - 7.26 (m, 4H), $7.24-7.13$ (m, 3H), $7.06-6.98$ (m, 2H), 6.90 (d, J=2.8 Hz, $1 \mathrm{H}), 3.82(\mathrm{~s}, 3 \mathrm{H}) \mathrm{ppm} .{ }^{13} \mathrm{C} \mathrm{NMR}\left(125 \mathrm{MHz}, \mathrm{CDCl}_{3}\right) \delta 162.2,155.5,152.2,146.8,133.7,132.9,132.9$, 130.1, 129.4, 127.8, 127.5, 127.4, 120.8, 118.8, 118.3, 118.0, 115.4, 56.0 ppm. HRMS (ESI): Calcd for $\mathrm{C}_{20} \mathrm{H}_{17} \mathrm{NO}_{2} \mathrm{~S}, 335.0980$ : Found: 336.1057, [M+H] ${ }^{+}$.

L7; Yellow solid in 91\% isolated yield. ${ }^{1} \mathrm{H}$ NMR (500 MHz, Chloroform- $d$ ) $\delta 14.16(\mathrm{~s}, 1 \mathrm{H}), 8.69(\mathrm{~s}, 1 \mathrm{H})$, 8.40 (s, 1H), 8.30 (d, $J=9.1 \mathrm{~Hz}, 1 \mathrm{H}), 7.45$ (d, $J=7.7 \mathrm{~Hz}, 2 \mathrm{H}), 7.41-7.22$ (m, 7H), 7.14 (d, $J=9.1 \mathrm{~Hz}$, 1H) ppm. ${ }^{13} \mathrm{C}$ NMR $\left(125 \mathrm{MHz}, \mathrm{CDCl}_{3}\right) \delta 166.6,160.5,145.6,140.0,133.5,133.1,132.6,130.9,129.5$, 128.5, 128.5, 128.4, 128.0, 127.9, 118.4, 118.3, 118.1 ppm. MS, HRMS (ESI): Calcd for $\mathrm{C}_{19} \mathrm{H}_{14} \mathrm{~N}_{2} \mathrm{O}_{3} \mathrm{~S}$, 350.0725: Found: 351.0801, [M+H] $]^{+}$

L8; Yellow solid in 84\% yield. ${ }^{1} \mathrm{H}$ NMR $(500 \mathrm{MHz}$, Chloroform- $d$ ) $\delta 15.22(\mathrm{~d}, J=2.8 \mathrm{~Hz}, 1 \mathrm{H}), 9.39$ (d, $J$ $=2.9 \mathrm{~Hz}, 1 \mathrm{H}), 8.12(\mathrm{~d}, J=8.4 \mathrm{~Hz}, 1 \mathrm{H}), 7.83(\mathrm{~d}, J=9.1 \mathrm{~Hz}, 1 \mathrm{H}), 7.75(\mathrm{~d}, J=7.9 \mathrm{~Hz}, 1 \mathrm{H}), 7.54(\mathrm{t}, J=7.7$ 
$\mathrm{Hz}, 1 \mathrm{H}), 7.48-7.44(\mathrm{~m}, 2 \mathrm{H}), 7.41-7.32(\mathrm{~m}, 5 \mathrm{H}), 7.31-7.26(\mathrm{~m}, 2 \mathrm{H}), 7.24-7.15(\mathrm{~m}, 2 \mathrm{H}) \mathrm{ppm} .{ }^{13} \mathrm{C}$ NMR $\left(125 \mathrm{MHz}, \mathrm{CDCl}_{3}\right) \delta 167.5,156.0,145.9,136.2,134.1,133.1,132.3,131.6,131.2,129.4,129.4$, $128.1,128.0,127.6,127.6,127.0,123.6,121.4,119.1,118.1,109.3$ ppm. HRMS (ESI): Calcd for $\mathrm{C}_{23} \mathrm{H}_{17} \mathrm{NOS}, 355.1031$ : Found: 356.1118, $[\mathrm{M}+\mathrm{H}]^{+}$.

\subsubsection{General procedure for the synthesis of $\mathbf{C 1}-\mathbf{C} \boldsymbol{8}$}

$42 \mathrm{mg}, 0.1 \mathrm{mmol} \mathrm{K}_{2} \mathrm{PtCl}_{4}$ was taken $2 \mathrm{~mL}$ of DMSO and stirred vigorously at $50{ }^{\circ} \mathrm{C}$ to get a red solution. $0.1 \mathrm{mmol}$ of ligand (L1-L8) and $0.1 \mathrm{mmol}$ of solid NaOAc were weighed together and added to Pt mixture at the same temperature $\left(50^{\circ} \mathrm{C}\right) .30 \mathrm{~mL}$ of $\mathrm{MeOH}$ was added to the mixture and the temperature was raised to reflux with constant stirring. The mixture was maintained at that condition for $6 \mathrm{~h}$ while a yellow to orange solid was precipitated. The mixture was cooled to ambient temperature, the solid precipitate was filtered washed successively with $10 \mathrm{~mL}$ methanol, $10 \mathrm{~mL}$ water and $30 \mathrm{~mL}$ methanol. Depending on the ligand orange to red solid complex was recovered in excellent yields and characterized, the characterization data were enlisted below and the original spectra were given in the supporting information.

C1, 72\% yield, light orange solid. ${ }^{1} \mathrm{H}$ NMR (400 MHz, DMSO- $\left.d_{6}\right) \delta 9.72(\mathrm{~s}, 1 \mathrm{H}), 8.52$ (d, $J=8.6 \mathrm{~Hz}$, $1 \mathrm{H}), 7.91(\mathrm{~d}, J=8.0 \mathrm{~Hz}, 1 \mathrm{H}), 7.86-7.68(\mathrm{~m}, 3 \mathrm{H}), 7.60(\mathrm{~s}, 2 \mathrm{H}), 7.55-7.44(\mathrm{~m}, 3 \mathrm{H}), 7.41$ (t, $J=7.5 \mathrm{~Hz}$, $1 \mathrm{H}), 6.99(\mathrm{~d}, J=8.6 \mathrm{~Hz}, 1 \mathrm{H}), 6.80(\mathrm{t}, J=7.3 \mathrm{~Hz}, 1 \mathrm{H}) \mathrm{ppm} .{ }^{13} \mathrm{C}$ NMR $\left(100 \mathrm{MHz}, \mathrm{DMSO}-d_{6}\right) \delta 163.0$, $154.1,153.1,137.4,136.5,132.7,132.4,132.0$, 131.7, 130.4, 130.2, 129.2, 121.1, 120.9, 119.2, 117.5, 115.0 ppm. HRMS (ESI): Calcd for $\mathrm{C}_{19} \mathrm{H}_{14} \mathrm{ClNOPtS}, 534.0132$ : Found: 557.0037, [M+Na $]^{+}$.

C2, 83\% yield, light orange solid. ${ }^{1} \mathrm{H}$ NMR (400 MHz, DMSO- $\left.d_{6}\right) \delta 9.66(\mathrm{~s}, 1 \mathrm{H}), 8.51(\mathrm{~d}, J=8.6 \mathrm{~Hz}$, $1 \mathrm{H}), 7.79(\mathrm{~d}, J=8.2 \mathrm{~Hz}, 1 \mathrm{H}), 7.76(\mathrm{~d}, J=7.7 \mathrm{~Hz}, 2 \mathrm{H}), 7.69$ (s, 1H), 7.61 (t, $J=7.8 \mathrm{~Hz}, 1 \mathrm{H}), 7.56-7.44$ $(\mathrm{m}, 4 \mathrm{H}), 7.41(\mathrm{t}, J=7.5 \mathrm{~Hz}, 1 \mathrm{H}), 6.93(\mathrm{~d}, J=8.7 \mathrm{~Hz}, 1 \mathrm{H}), 2.30(\mathrm{~s}, 3 \mathrm{H}) \mathrm{ppm} .{ }^{13} \mathrm{C}$ NMR $(100 \mathrm{MHz}$, DMSO- $\left.d_{6}\right) \delta 161.6,153.6,153.1,139.2,135.0,132.7,132.4,132.0,131.7,130.4,130.1,129.1,125.8$, 120.7, 120.6, 119.1, 20.1. HRMS (ESI): Calcd for $\mathrm{C}_{20} \mathrm{H}_{16} \mathrm{ClNOPtS,} \mathrm{548.0289:} \mathrm{Found:} \mathrm{571.0190,}$ $[\mathrm{M}+\mathrm{Na}]^{+}$.

C3, 81\% yield, reddish solid. ${ }^{1} \mathrm{H}$ NMR (400 MHz, DMSO- $\left.d_{6}\right) \delta 9.72(\mathrm{~s}, 1 \mathrm{H}), 8.46(\mathrm{~d}, J=8.6 \mathrm{~Hz}, 1 \mathrm{H})$, $7.84-7.68(\mathrm{~m}, 4 \mathrm{H}), 7.62(\mathrm{t}, J=7.8 \mathrm{~Hz}, 1 \mathrm{H}), 7.58-7.38(\mathrm{~m}, 5 \mathrm{H}), 7.00(\mathrm{dd}, J=9.3,4.6 \mathrm{~Hz}, 1 \mathrm{H}) \mathrm{ppm} .{ }^{19} \mathrm{~F}$ NMR (375 MHz, DMSO- $\left.d_{6}\right) \delta-128.82(\mathrm{dt}, J=8.0,4.3 \mathrm{~Hz}) \mathrm{ppm} .{ }^{13} \mathrm{C}$ NMR $\left(100 \mathrm{MHz}, \mathrm{DMSO}-d_{6}\right) \delta$ $159.88,153.78(\mathrm{~d}, J=232.2 \mathrm{~Hz}), 153.40,153.37,152.86,132.78,132.47,132.23,132.06,131.73$, 130.44, 129.39, 125.91 (d, $J=24.9 \mathrm{~Hz}), 122.51$ (d, $J=8.1 \mathrm{~Hz}), 119.91$ (d, $J=8.8 \mathrm{~Hz}), 119.21,118.42(\mathrm{~d}$, $J=22.7 \mathrm{~Hz}$ ) ppm. HRMS (ESI): Calcd for $\mathrm{C}_{19} \mathrm{H}_{13} \mathrm{ClFNOPtS}, 552.0038$ : Found: 574.9943, [M+Na] $]^{+}$ 
C4, 83\% yield, reddish orange solid. ${ }^{1} \mathrm{H}$ NMR $\left(500 \mathrm{MHz}, \mathrm{DMSO}-d_{6}\right) \delta 9.77(\mathrm{~s}, 1 \mathrm{H}), 8.53-8.46(\mathrm{~m}, 1 \mathrm{H})$, $8.17(\mathrm{~d}, J=2.7 \mathrm{~Hz}, 1 \mathrm{H}), 7.82(\mathrm{dd}, J=7.9,1.4 \mathrm{~Hz}, 1 \mathrm{H}), 7.80-7.76(\mathrm{~m}, 2 \mathrm{H}), 7.71(\mathrm{dd}, J=9.1,2.7 \mathrm{~Hz}$, $1 \mathrm{H}), 7.65(\mathrm{ddd}, J=8.7,7.1,1.4 \mathrm{~Hz}, 1 \mathrm{H}), 7.57-7.42(\mathrm{~m}, 4 \mathrm{H}), 6.98(\mathrm{~d}, J=9.1 \mathrm{~Hz}, 1 \mathrm{H}) \mathrm{ppm} .{ }^{13} \mathrm{C}$ NMR $\left(125 \mathrm{MHz}, \mathrm{DMSO}-d_{6}\right) \delta 161.9,153.5,152.8,139.2,137.4,132.8,132.6,132.2,132.1,131.8,130.6$, 130.5, 129.5, 123.4, 122.8, 119.4, 107.6 ppm. HRMS (ESI): Calcd for $\mathrm{C}_{19} \mathrm{H}_{13} \mathrm{Cl}_{2} \mathrm{NOPtS}, 567.9743$ : Found: $590.9634,[\mathrm{M}+\mathrm{Na}]^{+}$.

C5, 88\% yield, light solid. ${ }^{1} \mathrm{H}$ NMR (400 MHz, DMSO- $\left.d_{6}\right) \delta 9.75(\mathrm{~s}, 1 \mathrm{H}), 8.47$ (d, $\left.J=7.6 \mathrm{~Hz}, 1 \mathrm{H}\right), 8.15$ (s, 1H), $7.81(\mathrm{~d}, J=7.5 \mathrm{~Hz}, 1 \mathrm{H}), 7.76(\mathrm{~d}, J=6.0 \mathrm{~Hz}, 2 \mathrm{H}), 7.70(\mathrm{~d}, J=8.3 \mathrm{~Hz}, 1 \mathrm{H}), 7.66-7.59$ (m, 1H), $7.57-7.38(\mathrm{~m}, 4 \mathrm{H}), 6.96(\mathrm{~d}, J=8.7 \mathrm{~Hz}, 1 \mathrm{H}) \mathrm{ppm} .{ }^{13} \mathrm{C}$ NMR (125 MHz, DMSO-d $) \delta 161.9,153.6$, 152.8, 139.2, 137.4, 132.8, 132.6, 132.2, 132.1, 131.8, 130.6, 130.5, 129.5, 123.4, 122.8, 119.4, 107.6 ppm. HRMS (ESI): Calcd for $\mathrm{C}_{19} \mathrm{H}_{13} \mathrm{ClBrNOPtS}, 611.9237$ : Found: 634.9130, [M+Na] $]^{+}$

C6, 82\% yield, red solid. ${ }^{1} \mathrm{H}$ NMR $\left(500 \mathrm{MHz}, \mathrm{DMSO}-d_{6}\right) \delta 9.72(\mathrm{~s}, 1 \mathrm{H}), 8.50(\mathrm{~d}, J=8.6 \mathrm{~Hz}, 1 \mathrm{H}), 7.84-$ $7.74(\mathrm{~m}, 3 \mathrm{H}), 7.62(\mathrm{t}, J=7.8 \mathrm{~Hz}, 1 \mathrm{H}), 7.55-7.46(\mathrm{~m}, 3 \mathrm{H}), 7.45-7.39(\mathrm{~m}, 2 \mathrm{H}), 7.35$ (dd, $J=9.2,3.2 \mathrm{~Hz}$, 2H), $6.97(\mathrm{~d}, J=9.3 \mathrm{~Hz}, 1 \mathrm{H}), 3.79(\mathrm{~s}, 4 \mathrm{H}) \mathrm{ppm} .{ }^{13} \mathrm{C}$ NMR (125 MHz, DMSO-d 6 ) $\delta$ 159.1, 153.2, 153.1, 150.6, 132.8, 132.5, 132.4, 132.0, 131.7, 130.4, 130.0, 129.1, 128.5, 122.0, 119.8, 119.0, 114.4, 56.0. HRMS (ESI): Calcd for $\mathrm{C}_{20} \mathrm{H}_{16} \mathrm{ClNO}_{2} \mathrm{PtS}, 564.0238$ : Found: 587.0144, [M+Na $]^{+}$.

C7, 91\% yield, yellow orange solid. ${ }^{1} \mathrm{H}$ NMR (500 MHz, DMSO- $\left.d_{6}\right) \delta 10.04(\mathrm{~s}, 1 \mathrm{H}), 9.12(\mathrm{~d}, J=3.0 \mathrm{~Hz}$, $1 \mathrm{H}), 8.57(\mathrm{~d}, J=8.5 \mathrm{~Hz}, 1 \mathrm{H}), 8.39(\mathrm{dd}, J=9.4,3.0 \mathrm{~Hz}, 1 \mathrm{H}), 7.86(\mathrm{~d}, J=7.8 \mathrm{~Hz}, 1 \mathrm{H}), 7.81(\mathrm{~d}, J=7.3 \mathrm{~Hz}$, 2H), 7.69 (t, $J=7.9 \mathrm{~Hz}, 1 \mathrm{H}), 7.59-7.45(\mathrm{~m}, 4 \mathrm{H}), 7.13$ (d, $J=9.4 \mathrm{~Hz}, 1 \mathrm{H}) \mathrm{ppm}$. HRMS (ESI): Calcd for $\mathrm{C}_{19} \mathrm{H}_{13} \mathrm{ClN}_{2} \mathrm{O}_{3} \mathrm{PtS}$, 578.9983: Found: 601.9877, [M+Na] $]^{+}$

C8, 87\% yield, light orange solid. ${ }^{1} \mathrm{H}$ NMR (500 MHz, DMSO- $\left.d_{6}\right) \delta 10.11(\mathrm{~s}, 1 \mathrm{H}), 8.64(\mathrm{~d}, J=8.6 \mathrm{~Hz}$, $1 \mathrm{H}), 8.55(\mathrm{~d}, J=8.5 \mathrm{~Hz}, 1 \mathrm{H}), 8.12(\mathrm{~d}, J=9.2 \mathrm{~Hz}, 1 \mathrm{H}), 7.89(\mathrm{~d}, J=7.9 \mathrm{~Hz}, 1 \mathrm{H}), 7.83-7.78(\mathrm{~m}, 3 \mathrm{H}), 7.67$ $(\mathrm{t}, J=8.4 \mathrm{~Hz}, 1 \mathrm{H}), 7.61(\mathrm{t}, J=8.6 \mathrm{~Hz}, 1 \mathrm{H}), 7.57-7.48(\mathrm{~m}, 3 \mathrm{H}), 7.46-7.39(\mathrm{~m}, 2 \mathrm{H}), 7.20(\mathrm{~d}, J=9.2 \mathrm{~Hz}$, $1 \mathrm{H})$ ppm. ${ }^{13} \mathrm{C}$ NMR $\left(125 \mathrm{MHz}, \mathrm{DMSO}-d_{6}\right) \delta 164.5,153.9,146.9,138.2,134.0,132.7,132.6,132.5$, $132.0,131.7,130.5,129.6,129.4,128.7,128.5,128.0,124.3,123.7,122.1,119.6,111.8$ ppm. HRMS (ESI): Calcd for $\mathrm{C}_{23} \mathrm{H}_{16} \mathrm{ClNOPtS}, 584.0289$ : Found: 607.0186, [M+Na $]^{+}$. 


\subsection{Biology}

\subsubsection{Cell culturing}

MCF-7, MDA-MB-231 and SKBR3 cells were obtained from ATCC and maintained in DMEM (Gibco) supplemented with 10\% FBS (Gibco) and 0.1\% PEST (penicillin-streptomycin) (Merk Millipore). These cells were grown in incubator having $37^{\circ} \mathrm{C}$ and $5 \% \mathrm{CO}_{2}$.

\subsubsection{Cell viability assay}

Cell viability assay was determined using MTT assay. MCF-7, MDA-MB-231 and SKBR3 cells were treated with indicated complex for $48 \mathrm{~h}$ and then MTT assay was performed to determine cell viability. After treatment with complexes for $48 \mathrm{~h}$, MTT reagent (3-(4,5-Dimethylthiazol-2-yl)-2,5Diphenyltetrazolium Bromide) (Thermo Fisher Scientific) was added to control and drug treated cells for $3 \mathrm{~h}$ and cells were incubated in incubator at $37{ }^{\circ} \mathrm{C}$ and $5 \% \mathrm{CO}_{2}$. Then media was removed and $100 \mu \mathrm{L}$ of DMSO was added to each well to dissolve formazan crystals. Reading was taken at $490 \mathrm{~nm}$.

\subsubsection{Bright field images}

MCF-7, MDA-MB-231 and SKBR3 cells were treated with indicated complex for $48 \mathrm{~h}$ and then bright field images were taken to detect the cell morphology of both control and drug treated cells.

\subsubsection{Clonogenic assay}

MCF-7, MDA-MB-231 and SKBR3 cells were treated with DMSO, 0.5, 2.5 and $5 \mu \mathrm{M}$ of $\mathbf{C 1}, \mathbf{C 3}$ or $\mathbf{C 7}$ for 3 days. After $72 \mathrm{~h}$, drug containing media was removed from cell lines and fresh media containing DMEM supplemented with 10\% FBS and 0.1\% PEST (penicillin-streptomycin) was added to cell lines. Media was removed twice per week. After 9 days, media was removed and cells were washed 3 times with 1XPBS. Then cells were fixed with fixation solution (acetic acid:methanol 1:7) for 15 minutes at room temperature. After fixation, cell was stained with $0.5 \%$ crystal violet (Sigma Aldrich) solution for 30 minutes at room temperature. Crystal violet was removed and cells were washed with water to remove excess of crystal violet dye. Plates were scanned to take images.

\subsubsection{Crystal violet reading and absorbance}

After the procedure of crystal violet staining and scanning of plates, a mixture of acetic acid and 50\% ethanol (1:1) solution was added to each well to dissolve the crystal violet solution and then reading was performed at $570 \mathrm{~nm}$ to record absorbance. 


\subsubsection{Western Blot}

MCF-7, MDA-MB-231 and SKBR3 cells were treated with DMSO and indicated complex for $48 \mathrm{~h}$ to perform western blot. After treatment for $48 \mathrm{~h}$ cells were collected and spin down as a pellet. Cell pellets were washed with 1XPBS and then spin down to collect pellet. RIPA lysis buffer containing 1.0\% NP-40, $120 \mathrm{mM}$ sodium chloride, $50 \mathrm{mM}$ Tris $(\mathrm{pH} 8.0), 0.5 \%$ sodium deoxycholate and $0.1 \%$ SDS. Protease inhibitors cocktail was added to RIPA lysis buffer. RIPA lysis buffer were mixed with pellet to dissolve the pellet and cell lysates were kept on ice for 30 minutes to complete the cell lysis process and then centrifuged at $4{ }^{\circ} \mathrm{C}$ for 15 minutes to collect the supernatant. After protein quantification, samples were boiled in $5 \mathrm{X}$ loading buffer at $95{ }^{\circ} \mathrm{C}$ for 5 minutes using heating block. After gel running and gel transfer PVDF membrane was washed in 1X TBST. Blocking of proteins was performed in 5\% non-fat dry milk that was dissolved in 1X TBST. Blocking was performed for $1 \mathrm{~h}$ at $\mathrm{rt}$. Membrane was incubated with primary antibodies for overnight at $4{ }^{\circ} \mathrm{C}$. After removal of primary antibodies, membrane was washed three time with 1X TBST and then incubated with secondary antibody for $1 \mathrm{~h}$ at $\mathrm{rt}$. After removal of secondary antibody, membrane was washed three times with 1X TBST and incubated with ECL solution (Pierce ${ }^{\mathrm{TM}}$ ECL Western Blotting Substrate) to detect the signal.

\subsubsection{Wound healing assay}

MCF-7, MDA-MB-231 and SKBR3 cells were treated with DMSO and indicated compounds for $48 \mathrm{~h}$. Cells were plate at $90 \%$ confluence and next day scratch was performed using $10 \mu \mathrm{L}$ sterilize tip. Cells were washed with $1 \mathrm{X}$ PBS after scratch to remove cell debris. Then fresh DMEM media supplemented with $10 \%$ FBS and $0.1 \%$ PEST (penicillin-streptomycin) (Merck Millipore) was added to cell lines. Images were taken immediately after scratch and time was counted as $0 \mathrm{~h}$. Cells were further maintained in drug containing DMEM medium for next $24 \mathrm{~h}$ and then the scratched area was determined as $24 \mathrm{~h}$.

\subsubsection{Senescence $\beta$-Galactosidase Staining assay}

Senescence $\beta$-galactosidase staining assay was performed using senescence $\beta$-galactosidase staining kit \#9860 from cell signaling technology. MCF-7, MDA-MB-231 and SKBR3 cells were treated with DMSO and indicated complex for 5 days to determine cellular senescence using beta-galactosidase assay. Greenish color represented senescent cells. Senescence $\beta$-Galactosidase Staining assay was performed following instruction from protocol (Kit \#9860 CST).

\subsubsection{ATP production assay}

ATP production assay was performed using luminescent ATP detection assay kit from Abcam (ab113849). MDA-MB-231 cells were treated with $\mathbf{C 1}$ and $\mathbf{C 7}(10 \mu \mathrm{M})$ for 2 days and cellular ATP 
production was determined in percentage using ATP production kit. Experiment was performed following instruction from kit protocol.

\subsubsection{TUNEL apoptosis detection assay}

TUNEL Apoptosis was performed using TUNEL apoptosis detection assay kit CAT \#: KTA2010 from Abbkine. MCF-7, MDA-MB-231 and SKBR3 cells were treated with DMSO, C1, C3 or C7 (10 $\mu \mathrm{M})$ for $48 \mathrm{~h}$ and TUNEL assay was performed to detect cell death. Experiment was performed following instruction from kit protocol.

\subsubsection{Mammosphere formation assay}

MCF-7, MDA-MB-231 and SKBR3 breast cancer cells were grown as mammosphere/ cancer stem cells and then treated with $\mathbf{C 1}, \mathbf{C 3}$ and $\mathbf{C 7}(10 \mu \mathrm{M})$ for 7 days and the effect of these complexes on cancer stem cells formation was determined. Cells were grown in mammosphere medium using ultra-low attachment plates (Corning). Mammosphere medium was prepared using DMEM/F12 medium (Thermo Fisher Scientific), B27 supplement (Thermo Fisher Scientific), epidermal growth factor (EGF) (Thermo Fisher Scientific) and basic fibroblast growth factor (bFGF) (Sigma Aldrich). Bright field images were taken using microscope.

\section{Acknowledgements}

The authors acknowledge the Inner Mongolia University funding under the title Academic Backbone and “JUN-MA" High-level Talents Program of Inner Mongolia University (No 21300-5195112, No 213005205107)

\section{Appendix A. Supplementary data}

Supplementary data, stability figures, ${ }^{1} \mathrm{H},{ }^{13} \mathrm{C},{ }^{19} \mathrm{~F}$ NMR and MS spectra and other related data to this article can be found at http://dx.doi.org/10.

\section{References}

[1] T.C. Johnstone, G.Y. Park, S.J. Lippard, Understanding and improving platinum anticancer drugs-phenanthriplatin, Anticancer Res., 34(2014) 471-6.

[2] S.J. Berners-Price, Activating platinum anticancer complexes with visible light, Angew. Chem. Int. Ed., 50(2011) 804-5. 
[3] N.J. Wheate, S. Walker, G.E. Craig, R. Oun, The status of platinum anticancer drugs in the clinic and in clinical trials, Dalton Trans, 39(2010) 8113-27.

[4] N. Cutillas, G.S. Yellol, C. de Haro, C. Vicente, V. Rodríguez, J. Ruiz, Anticancer cyclometalated complexes of platinum group metals and gold, Coord. Chem. Rev., 257(2013) 2784-97.

[5] F.M. Muggia, A. Bonetti, J.D. Hoeschele, M. Rozencweig, S.B. Howell, Platinum antitumor complexes: 50 Years since Barnett Rosenberg's discovery, J Clin Oncol, 33(2015) 4219-26.

[6] B. Rosenberg, L. Vancamp, J.E. Trosko, V.H. Mansour, Platinum compounds - A new class of potent antitumour agents, Nature, 222(1969) 385-6.

[7] B. Rosenberg, L. Vancamp, E.B. Grimley, A.J. Thomson, Inhibition of growth or cell division in Escherichia Coli by different ionic species of platinu(IV) complexes, J. Biol. Chem., 242(1967) 1347-52.

[8] B. Rosenberg, E. Renshaw, L. Vancamp, J. Hartwick, J. Drobnik, Platinum induced filamentous growth in Escherichia Coli, J. Bacteriol., 93(1967) 716-21.

[9] B. Rosenberg, L. Vancamp, T. Krigas, Inhibition of cell division in Escherichia Coli by electrolysis products from a platinum electrode, Nature, 205(1965) 698-9.

[10] B. Rosenberg, L. VanCamp, J.E. Trosko, V.H. Mansour, Platinum compounds: A new class of potent antitumour agents, Nature, 222(1969) 385-6.

[11] R.G. Kenny, C.J. Marmion, Toward multi-targeted platinum and ruthenium drugs-A new Paradigm in cancer drug treatment regimens?, Chem. Rev., 119(2019) 1058-137.

[12] A.R. Kapdi, I.J. Fairlamb, Anti-cancer palladium complexes: A focus on $\operatorname{PdX}_{2} \mathrm{~L}_{2}$, palladacycles and related complexes, Chem. Soc. Rev., 43(2014) 4751-77.

[13] X. Wang, Z. Guo, Targeting and delivery of platinum-based anticancer drugs, Chem. Soc. Rev., 42(2013) 202-24.

[14] E. Wong, C.M. Giandomenico, Current Status of platinum-based antitumor drugs, Chem. Rev., 99(1999) 2451-66.

[15] C. Holohan, S. Van Schaeybroeck, D.B. Longley, P.G. Johnston, Cancer drug resistance: an evolving paradigm, Nat. Rev. Cancer, 13(2013) 714-26.

[16] B. Köberle, M.T. Tomicic, S. Usanova, B. Kaina, Cisplatin resistance: Preclinical findings and clinical implications, Biochim. Biophys. Acta, 1806(2010) 172-82.

[17] N. Milosavljevic, C. Duranton, N. Djerbi, P.H. Puech, P. Gounon, D. Lagadic-Gossmann, M.T. Dimanche-Boitrel, C. Rauch, M. Tauc, L. Counillon, M. Poet, Nongenomic effects of cisplatin: acute inhibition of mechanosensitive transporters and channels without actin remodeling, Cancer Res., 70(2010) 7514-22.

[18] R.S.A. J A Levi, D N Dalley, Haemolytic anemia after cisplatin, Br. Med. J., 282(1981) 2003-4.

[19] J.R. García-Berrocal, J. Nevado, R. Ramírez-Camacho, R. Sanz, J.A. González-García, C. SánchezRodríguez, B. Cantos, P. España, J.M. Verdaguer, A. Trinidad Cabezas, The anticancer drug cisplatin induces an intrinsic apoptotic pathway inside the inner ear, Br. J. Pharmacol., 152(2007) 1012-20.

[20] D.J. Stewart, Mechanisms of resistance to cisplatin and carboplatin, Crit Rev Oncol Hematol, 63(2007) 12-31.

[21] B.W. Harper, A.M. Krause-Heuer, M.P. Grant, M. Manohar, K.B. Garbutcheon-Singh, J.R. AldrichWright, Advances in platinum chemotherapeutics, Chem. Eur. J., 16(2010) 7064-77.

[22] J.J. Wilson, S.J. Lippard, Synthetic methods for the preparation of platinum anticancer complexes, Chem. Rev., 114(2013) 4470-95.

[23] Z. Guo, W.L. Tong, M.C. Chan, Luminescent oligo(ethylene glycol)-functionalized cyclometalated platinum(II) complexes: cellular characterization and mitochondria-specific localization, Chem Commun (Camb), 50(2014) 1711-4.

[24] G. Ma, Y. Min, F. Huang, T. Jiang, Y. Liu, Thioether binding mediates monofunctional platinum antitumor reagents to trans configuration in DNA interactions, Chem. Commun., 46(2010) 6938-40.

[25] D. Wang, G. Zhu, X. Huang, S.J. Lippard, X-ray structure and mechanism of RNA polymerase II stalled at an antineoplastic monofunctional platinum-DNA adduct, PNAS, 107(2010) 9584-9. 
[26] S.E. Sherman, S.J. Lippard, Structural aspects of platinum anticancer drug interactions with DNA, Chem. Rev., 87(1987) 1153-81.

[27] I. Romero-Canelón, P.J. Sadler, Next-generation metal anticancer complexes: Multitargeting via redox modulation, Inorg. Chem., 52(2013) 12276-91.

[28] P. Liu, Y. Lu, X. Gao, R. Liu, D. Zhang-Negrerie, Y. Shi, Y. Wang, S. Wang, Q. Gao, Highly watersoluble platinum(II) complexes as GLUT substrates for targeted therapy: improved anticancer efficacy and transporter-mediated cytotoxic properties, Chem Commun (Camb), 49(2013) 2421-3.

[29] J.S. Butler, P.J. Sadler, Targeted delivery of platinum-based anticancer complexes, Curr. Opin. Chem. Biol., 17(2013) 175-88.

[30] K.D. Mjos, C. Orvig, Metallodrugs in medicinal inorganic chemistry, Chem. Rev., 114(2014) 454063.

[31] S. Dilruba, G.V. Kalayda, Platinum-based drugs: past, present and future, Cancer Chemother Pharmacol, 77(2016) 1103-24.

[32] G.Y. Park, J.J. Wilson, Y. Song, S.J. Lippard, Phenanthriplatin, a monofunctional DNA-binding platinum anticancer drug candidate with unusual potency and cellular activity profile, PNAS, 109(2012) 11987-92.

[33] T.C. Johnstone, S.M. Alexander, W. Lin, S.J. Lippard, Effects of monofunctional platinum agents on bacterial growth: a retrospective study, J. Am. Chem. Soc., 136(2014) 116-8.

[34] T.C. Johnstone, S.J. Lippard, The chiral potential of phenanthriplatin and its influence on guanine binding, J. Am. Chem. Soc., 136(2014) 2126-34.

[35] M. Galanski, M.A. Jakupec, B.K. Keppler, Update of the preclinical situation of anticancer platinum complexes: novel design strategies and innovative analytical approaches, Curr. Med. Chem., 12(2005) 2075-94.

[36] Y. Feng, M. Spezia, S. Huang, C. Yuan, Z. Zeng, L. Zhang, X. Ji, W. Liu, B. Huang, W. Luo, B. Liu, Y. Lei, S. Du, A. Vuppalapati, H.H. Luu, R.C. Haydon, T.C. He, G. Ren, Breast cancer development and progression: Risk factors, cancer stem cells, signaling pathways, genomics, and molecular pathogenesis, Genes Dis, 5(2018) 77-106.

[37] S. Al-Mahmood, J. Sapiezynski, O.B. Garbuzenko, T. Minko, Metastatic and triple-negative breast cancer: challenges and treatment options, Drug Deliv Transl Res, 8(2018) 1483-507.

[38] L. Yin, J.J. Duan, X.W. Bian, S.C. Yu, Triple-negative breast cancer molecular subtyping and treatment progress, Breast Cancer Res, 22(2020) 61.

[39] J. Wang, B. Xu, Targeted therapeutic options and future perspectives for HER2-positive breast cancer, Signal Transduct Target Ther, 4(2019) 34.

[40] P.A. Muller, K.H. Vousden, Mutant p53 in cancer: New functions and therapeutic opportunities, Cancer Cell, 25(2014) 304-17.

[41] X. Zhou, Q. Hao, H. Lu, Mutant p53 in cancer therapy-the barrier or the path, J Mol Cell Biol, 11(2019) 293-305.

[42] M.M. Moasser, The oncogene HER2: its signaling and transforming functions and its role in human cancer pathogenesis, Oncogene, 26(2007) 6469-87.

[43] F.-U. Rahman, A. Ali, R. Guo, Y.-C. Zhang, H. Wang, Z.-T. Li, D.-W. Zhang, Synthesis and anticancer activities of a novel class of mono- and di-metallic Pt(II)(salicylaldiminato)(DMSO or picolino)Cl complexes, Dalton Trans, 44(2015) 2166-75.

[44] M.D. Hall, K.A. Telma, K.E. Chang, T.D. Lee, J.P. Madigan, J.R. Lloyd, I.S. Goldlust, J.D. Hoeschele, M.M. Gottesman, Say no to DMSO: dimethylsulfoxide inactivates cisplatin, carboplatin, and other platinum complexes, Cancer Res., 74(2014) 3913-22.

[45] J. Reedijk, Platinum anticancer coordination compounds: study of DNA binding inspires new drug design, Eur. J. Inorg. Chem., 2009(2009) 1303-12.

[46] S. Ahmad, Kinetic aspects of platinum anticancer agents, Polyhedron, 138(2017) 109-24.

[47] L. Cubo, D.S. Thomas, J. Zhang, A.G. Quiroga, C. Navarro-Ranninger, S.J. Berners-Price, $\left[{ }^{1} \mathrm{H},{ }^{15} \mathrm{~N}\right]$ NMR studies of the aquation of cis-diamine platinum(II) complexes, Inorg. Chim. Acta, 362(2009) 1022-6. 
[48] X. Dai, H. Cheng, Z. Bai, J. Li, Breast cancer cell line classification and its relevance with breast tumor Subtyping, J Cancer, 8(2017) 3131-41.

[49] L. Yang, P. Shi, G. Zhao, J. Xu, W. Peng, J. Zhang, G. Zhang, X. Wang, Z. Dong, F. Chen, H. Cui, Targeting cancer stem cell pathways for cancer therapy, Signal Transduct Target Ther, 5(2020) 8.

[50] O.V. Dolomanov, L.J. Bourhis, R.J. Gildea, J.A.K. Howard, H. Puschmann, OLEX2: a complete structure solution, refinement and analysis program, J. Appl. Crystallogr., 42(2009) 339-41.

[51] D. Kratzert, J.J. Holstein, I. Krossing, DSR: enhanced modelling and refinement of disordered structures with SHELXL, J. Appl. Crystallogr., 48(2015) 933-8.

[52] V.K. Madduluri, N. Baig, S. Chander, S. Murugesan, A.K. Sah, Mo(VI) complex catalysed synthesis of sulfones and their modification for anti-HIV activities, Catal. Comm., 137(2020) 105931. 